\title{
Proportion of T Follicular Helper Cells in Peripheral Blood of Rheumatoid Arthritis Patients: A Systematic Review and Meta-Analysis
}

\author{
Peyman Bemani \\ Shiraz University of Medical Sciences \\ Kari K. Eklund \\ Department of medicine,division of rhumatology,Helsinki university \\ Mohammad Ali-Hassanzadeh \\ Department of immunology, Giroft univesity of medical scinences \\ Dieter Kabelitz \\ Institut of immunnology, Keil university \\ Reinhold E. Schmidt \\ Klinic fur immunologie and rheumatologie hannover, Germany \\ Seppo Meri \\ Department of immunology and bacteriology, university of Helsinki, Finland \\ Kurosh Kalantar ( $\square$ kalantark@sums.ac.ir) \\ Shiraz University of Medical Sciences https://orcid.org/0000-0002-9160-9449
}

\section{Research article}

Keywords: T follicular helper cells, Tfh, Rheumatoid arthritis, Systematic review, Meta-analysis

Posted Date: October 14th, 2020

DOl: https://doi.org/10.21203/rs.3.rs-88912/v1

License: (c) (i) This work is licensed under a Creative Commons Attribution 4.0 International License. Read Full License 


\section{Abstract}

Objectives: Follicular helper T (Tfh) cells have critical roles in the development and promotion of humoral immune responses. Accumulating evidence points to alterations in the levels and activity of Tfh which may lead to impaired immune tolerance and development of antibody-mediated autoimmune diseases, such as rheumatoid arthritis (RA). To elucidate the status of Tfh cells in patients with RA, we conducted a systematic review and meta-analysis to assess the proportion and types of Tfh cells in the PB of RA patients.

Method: We systematically searched databases of Embase, Pubmed, Web of sciences (WOS), and Scopus to identify the eligible articles. We performed meta-analysis to assess the proportion of Tfh cells in PB of RA patients compared to healthy controls (HCs). We also assessed the proportion of Tfh cells based on different parameters including Tfh definition markers, disease activity status, disease stage, treatment status, serum markers, and the geographical location of the included articles.

Results: Regardless of definition markers, the proportion of Tfh cells in RA patients was significantly higher than that in HCs (SMD 0.75, [0.56, 0.93], $\mathrm{p}<0.0001)$. Based on subgroup analyses, the proportion of Tfh cells with the individual definitions were also significantly higher in PB of RA patients compared to HCs. Tfh cells proportion in untreated-RA and early-RA patients was markedly greater than HCs, when comparisons were made without considering the definition markers, and also when Tfh cells was defined by the specified definition markers. While the proportion of Tfh cells by all definitions was significantly higher in active- and remission-RA compared to $\mathrm{HCs}$, individual analysis of two definitions, $\mathrm{CD} 4^{+} \mathrm{CXCR} 5^{+}$and $\mathrm{CD}^{+}{ }^{+} \mathrm{CXCR} 5^{+} I \mathrm{COS}^{+}$, didn't show significant differences. In addition, higher proportion of Tfh cells defined by all definitions as well as a specified definition $\left(C D 4^{+}\right.$CXCR5 $\left.{ }^{+} P D-1^{\text {high }}\right)$ was observed when $S^{+} R A$ and S'RA patients were compared to the HCs. Higher Tfh cells proportion in RA patients compared with HCs was observed in the Asian populations (SMD 0.89, $[0.68,1.09], p<0.0001)$, while there was a trend toward significant in the proportion of Tfh between the two groups in non-Asians (SMD 0.29, [-0.003, 0.59], p=0.052).

Conclusion: Altogether, our results demonstrate that circulating Tfh are highly elevated in RA patients and are also significantly increased in untreated-, early- and $\mathrm{S}^{+}$-RA patients, underscoring the potential pathogenic role of this cell population in RA and its potential use as a biomarker and a target for RA therapy.

\section{Introduction}

Rheumatoid arthritis (RA) is a chronic autoimmune disease with a prevalence of $0.5-1 \%$ of the population, and primarily affecting joint tissues [1]. Typical clinical manifestations include symmetrical inflammation and swelling in particular of the small joints of hands and feet, which can lead to joint destruction, deformity and functional disability [1, 2]. RA imposes a substantial socio-economic burden on patients and societies [2, 3]. Although, the exact etiology and pathogenesis of RA are not completely understood, it is well accepted that the disease is multifactorial caused by multiple genetic, environmental, and microbial factors. These risk factors together trigger uncontrolled immune responses, and development and progression of the disease [2].

Different types of innate and adaptive immune cells including dendritic cells (DCs), monocytes, macrophages, antigen-specific T and B lymphocytes along with cytokines and autoantibodies contribute to the pathogenesis of RA [3]. Among the immune cells, CD4 ${ }^{+} \mathrm{T}$ cells have critical roles in the disease induction and progression. Once activated, $C D 4^{+} \mathrm{T}$ cell can differentiate into different $\mathrm{T}$ helper (Th) subsets including Th1, Th2, Th17, T regulatory or $\mathrm{T}$ follicular helper (Tfh) cells, each play an important role in the RA [4].

Tfh cells are a subpopulation of Th cells localized in the B cell follicle of lymph nodes. These cells are essential in humoral immune response by providing help for B cell to develop germinal center, differentiate to memory B cells and long-lived antibody-secreting plasma cell, immunoglobulin classswitching and antibody affinity maturation $[5,6]$. Tfh cells can be distinguished from other differentiated CD $4^{+}$Th subsets by the expression of B-cell lymphoma 6 (BCL-6) transcription factor [7], the surface expression of CXCR5 chemokine receptor [8-10], CD40 ligand, programmed cell death protein 1 (PD-1), and inducible costimulatory molecule (ICOS) [6, 11], and the production an release of interleukin (IL)-21 [7].

Despite the prominent role of Tfh cells in humoral immunity for protection against infectious pathogens, accumulating evidence has demonstrated that deregulated frequency and activity of Tfh may lead to impaired immune tolerance, generation of high-affinity autoantibodies and hence development of antibody-mediated autoimmune diseases [12-15]. However, anatomical localization of Tfh cells in the secondary lymphoid tissues limits their routine studies in human patients $[6,8]$. Recently, studies have introduced a new circulating subpopulation of CD ${ }^{+} T$ cells that show both phenotypical and functional characteristics of classical Tfh cells residing in the lymphoid tissues [16, 17]. Based on these studies, circulating Tfh (cTfh) cells, similar to the classical Tfh, could promote differentiation of naïve B cell into plasma cells and immunoglobulin secretion through IL-21 production [16]. In addition studies have shown that cTfh cells increase in proportion to their GC counterparts in secondary lymphoid tissues [17]. Thus, they represent circulating compartment of Tfh cells and evaluation of the status of cTfh would reflect the status of their counterpart in GC of secondary lymphoid tissues [16, 17]. Following the introduction of cTfh, several human studies have demonstrated the increased frequency of Tfh in the peripheral blood (PB) of patients with different autoimmune diseases including systemic lupus erythematosus, autoimmune thyroiditis, myasthenia gravis, Sjogren's syndrome and RA [18].

Several research groups have explored the potential role of cTfh cells in RA pathogenesis by determining their frequency in PB of RA patients compared to the healthy controls (HCs). While some of these studies have shown increase in the frequency of Tfh in PB of patients with RA and its positive correlation with disease scores, some other studies have failed to show any differences in the frequency of these cells in patients with RA compared with

Page $2 / 20$ 
HCs. Hence, in the present work, we systematically searched and reviewed the available studies documenting the proportion of Tfh among CD $4^{+} T$ cells in PB of RA patients, and conducted a meta-analysis to elucidate the proportion of Tfh cells in the PB of RA patients compared to the HCs.

\section{Materials And Methods 2.1 Search Strategy}

This study was carried out in accordance with the Preferred Reporting Items for Systematic Reviews and Meta-Analyses (PRISMA) guidelines and was registered at the international prospective register of systematic reviews (PROSPERO) (CRD42020163549). We searched online databases including Embase, PubMed, Scopus and Web of Science (WOS) to identify original articles published until November 2019 reporting the frequency of Tfh among CD4 ${ }^{+}$T cells in PB of patients with RA. The search terms used in this meta-analysis were as follows: ("Arthritis, Rheumatoid"[Mesh] OR "Rheumatoid arthritis" OR RA) AND ("T helper follicular" OR "T follicular helper" OR "Follicular T helper" OR "Follicular helper T" OR "Tfh"). In order to reduce the risk of missing any related study, we also searched manually the reference list of review articles and the included original articles. The searches and selection of articles were conducted by two investigators independently. In the case of any disagreement, it was resolved through discussion with a third investigator.

\subsection{Study selection}

Inclusion criteria: 1) original human studies; 2) title or abstract containing the terms "rheumatoid arthritis" or "RA" and "T helper follicular" OR "T follicular helper" OR "follicular T helper" OR "follicular helper T" OR "Tfh"; 3) documenting the frequency/proportion of Tfh among CD4+ T cells in the PB of RA patients and HCs; 4) available as full-text article on the internet (website or PDF); 5) Available information regarding the number of patients and HCs. No restriction was applied for the subtypes of the RA disease, disease severity score, sex or race of the participant subjects in the study. Also, no time or language restrictions were imposed.

Exclusion criteria: 1) non-original studies, review articles, case reports, letter to editor or conference abstract publications; 2) Animal or in vitro studies; 3) studies without healthy control group; 3 ) studies without raw data in which data extraction from their graphical results were not feasible; 4) Redundancies among Embase, PubMed, Scopus, and WOS search were removed and each study was counted only once in the meta-analysis

\subsection{Data extraction and quality assessment}

Two independent researchers carefully reviewed the included studies and extracted data, and disagreements were resolved through discussion with the third investigator. The following data were extracted from the eligible articles: author's name, publication year, country where the authors performed the analysis, number of RA patients and $\mathrm{HC}$ controls, Tfh definition, mean and standard deviation (SD) of the frequency of Tfh among CD4 ${ }^{+} \mathrm{T}$ cells. When Tfh were defined by different patterns of markers in the studies, data were extracted from all of them. If instead of mean and SD, the studies reported mean and standard error (SE), medians and ranges, or median and interquartile ranges we extracted all types of the data. In the case of some of articles presenting only graphical results without raw data in which it was not possible to extract data from their graphs, the raw data (mean and SD) were generously received from the authors after contacting the authors by email. The quality of all included studies was assessed by Newcastle-Ottawa Quality Assessment Scale (NOS) (Case Control Studies) [19].

\subsection{Data analysis}

All statistical analyses for the Tfh frequency differences between RA and HC subjects were conducted using STATA version 16.0 (Stata Corp., College Station, Texas). The sample size, mean, and SD of the frequency of Tfh cells were used to calculate the standardized mean difference (SMD) between RA and $\mathrm{HC}$ groups.

For certain studies reporting only graphical results, the graphs were converted to the numerical data by using GetDat Graph Digitizer software version 2.24 (http://getdata-graph-digitizer.com/). When some studies reported SE instead of SD, the SD was calculated from sample size and SE using the following formula: $S D=S E x \sqrt{n}$. When some studies presented their results as median and range, or median and interquartile range (IQR), the mean and SD were estimated by using a standard method [20]. When there was need to combine data from two subgroups (for example combining mean and SD of "active-RA" and those from "remission-RA" groups), the pooled mean and SD was calculated by using a standard formula according to the Cochrane Handbook for Systematic Reviews of Interventions [21].

The meta-analysis was performed to calculate the SMD of the proportion of Tfh among $C D 4^{+} \mathrm{T}$ cells in the PB of 1) RA patients versus HCs 2) untreated RA ( $u-R A)$ patients versus HCs, 3) early RA (e-RA) patients versus HCs, 4) active-RA (a-RA) patients versus in remission-RA (r-RA) patients, 5) a-RA patients versus $\mathrm{HCs}, 6)$ seropositive $\left(\mathrm{S}^{+}\right) \mathrm{RA}$ patients versus seronegative $\left(\mathrm{S}^{-}\right) \mathrm{RA}$ patients, and 7$) \mathrm{S}^{+} \mathrm{RA}$ patients versus HCs. Furthermore, since the studies used different patterns of markers to define Tfh cells, subgroup analysis was also performed to estimate the results based on each Tfh definition.

In order to evaluate the heterogeneity between the studies, the Q test and $\mathrm{I}^{2}$ statistic was used. For the Q test, P-value $<0.1$ was considered as statistically significant and $\mathrm{I}^{2}$ values of $75 \%, 50 \%$, and $25 \%$ were considered as evidence of high, moderate and low level of heterogeneity, respectively. SMD with $95 \%$ confidence interval ( $\mathrm{Cl}$, Hedges' g) was calculated to assess the proportion of Tfh cells, and random effect model (REM) was used when the heterogeneity was high $\left(I^{2}>50 \%\right)$, and a fixed effect model (FEM) was chosen when the heterogeneity was low or absent $\left(I^{2} \leq 50 \%\right)$. In addition, the publication bias was assessed by using funnel plot in which the $x$ - axes and $y$-axes of the plot were used to show SMD and SE. Egger's test was used for evaluating funnel 
plot asymmetry, and in the case of its presence, the "trim and fill" method was applied to assess the effect of publication bias on the calculated results. Pvalue $<0.05$ was considered to be statistically significant except where noted.

\section{Results}

\subsection{Literature Search}

A total of 821 potentially eligible studies were retrieved after searching databases along with manual searching. Of these, after primary screening, 405 and 365 studies were respectively excluded due to duplication and not satisfying the inclusion criteria. Fifty one relevant full-text articles were selected and assessed for eligibility, of which 26 articles were excluded because of the following reasons: lack of healthy control group $(n=3)$, evaluating the Tfh cells in in vitro $(n=4)$, without raw data and unable to extract data from the graphical result $(n=2)$, evaluating changes in the proportion of Tfh in autoimmune diseases other than RA $(n=1)$, reporting only the absolute number of Tfh cells $(n=2)$, overlapping samples from other studies ( $n=2)$, reporting only Tfh subsets (Tfh-1, -2 and -17$)(n=2)$, and letter to editor. Additional 10 articles were irrelevant and didn't evaluate proportion of Tfh cells, thus, finally a total of 25 articles were included in the meta-analysis (Fig. 1)

\subsection{Characteristics of eligible studies}

Of the included articles, 14 were performed in China, 4 in Japan, 2 in Spain, 1 in Sweden, 1 in Italy, 2 in USA, and 1 in Argentina. In total the eligible articles included 1041 RA patients and $626 \mathrm{HCs}$. According to the NOS risk of bias assessment, all the included studies had a score of 4-8, most of them had high quality (NOS score, 7 and 8), and fewer with moderate quality (NOS score, 4-6). The included studies and their basic characteristics were also listed in Table 1.

\subsection{The proportion of Tfh in the PB of RA patients versus HCs}

\subsubsection{Pooled results}

In initial step, we carried out meta-analysis to compare the proportion of Tfh cells between RA and HC groups regardless of the markers used for definition of Tfh cells. Some of these studies reported a significant increase in the proportion of Tfh cells in BP of RA versus HC subjects [22-34], some studies showed no differences [35-39], some studies revealed both increase in RA and no differences between the two groups depending on the definition markers [40-43], and some other reported non-significant decrease in Tfh cells proportion in RA group [44, 45]. Based on the pooled result of meta-analysis, RA patients had a significantly higher proportion of cTfh cells compared with HCs (SMD 0.75, [0.56, 0.93], p<0.0001), although high level of heterogeneity $\left(I^{2}=80.15, p<0.0001\right)$ was observed between studies (Fig. 2). 
Table 1

Basic characteristics of the included studies

\begin{tabular}{|c|c|c|c|c|c|c|c|c|c|c|c|}
\hline \multirow[t]{2}{*}{ Author } & \multirow[t]{2}{*}{ Year } & \multirow[t]{2}{*}{ Country } & \multirow{2}{*}{$\begin{array}{l}\text { RA } \\
\text { number }\end{array}$} & \multirow{2}{*}{$\begin{array}{l}\mathrm{HC} \\
\text { number }\end{array}$} & \multirow[t]{2}{*}{ Study } & \multirow[t]{2}{*}{ Tfh definition } & \multicolumn{4}{|c|}{$\%$ of Tfh cells in PB } & \multirow[t]{2}{*}{ NOS } \\
\hline & & & & & & & $\begin{array}{l}\text { RA } \\
\text { mean }\end{array}$ & RASD & $\begin{array}{l}\mathrm{HC} \\
\text { mean }\end{array}$ & HC SD & \\
\hline \multirow[t]{2}{*}{ Liu et al. [22] } & 2018 & China & 78 & 33 & a & $\mathrm{CD}^{+} \mathrm{CXCR}^{+}$ & 18.905 & 3.360 & 15.180 & 4.190 & \multirow[t]{2}{*}{7} \\
\hline & & & & & $b$ & $\mathrm{CD} 4^{+} \mathrm{CXCR} 5^{+} \mathrm{PD}-1^{\text {high }}$ & 7.070 & 2.800 & 3.590 & 1.010 & \\
\hline \multirow[t]{2}{*}{ Ma et al. [23] } & 2012 & China & 33 & 23 & a & $\mathrm{CD}^{+} \mathrm{CXCR}^{+}$ & 2.910 & 3.000 & 0.900 & 0.290 & \multirow[t]{2}{*}{4} \\
\hline & & & 29 & 22 & $b$ & $\mathrm{CD}^{+} \mathrm{CXCR}^{+} \mathrm{ICOS}^{\text {high }}$ & 0.140 & 0.180 & 0.020 & 0.020 & \\
\hline $\begin{array}{l}\text { Han et al. } \\
\text { [24] }\end{array}$ & 2018 & China & 20 & 12 & & $\mathrm{CD}^{+} \mathrm{CXCR}^{+}$ & 22.720 & 6.300 & 13.750 & 4.880 & 5 \\
\hline $\begin{array}{l}\text { Costantino et } \\
\text { al. [35] }\end{array}$ & 2017 & Argentina & 24 & 22 & & $\mathrm{CD}^{+}{ }^{+} \mathrm{CXCR} 5^{+}$ & 12.890 & 7.730 & 10.480 & 3.900 & 8 \\
\hline \multirow[t]{3}{*}{ An et al. [25] } & 2016 & China & 40 & 20 & a & $\mathrm{CD}^{+} \mathrm{CXCR}^{+}$ & 16.750 & 3.920 & 7.490 & 1.840 & \multirow[t]{3}{*}{7} \\
\hline & & & & & $b$ & $\mathrm{CD}^{+} \mathrm{CXCR}^{+} \mathrm{PD}-1^{+}$ & 1.570 & 1.100 & 0.240 & 0.300 & \\
\hline & & & & & c & $\mathrm{CD}^{+} \mathrm{CXCR}^{+} \mathrm{ICOS}^{+}$ & 8.370 & 4.280 & 3.720 & 1.810 & \\
\hline \multirow[t]{2}{*}{ He et al. [36] } & 2013 & China & 38 & 30 & a & $\mathrm{CD}^{+}{ }^{+} \mathrm{CXR} 5^{+}$ & 13.729 & 5.000 & 13.478 & 5.693 & \multirow[t]{2}{*}{6} \\
\hline & & & & & $b$ & $\begin{array}{l}\mathrm{CD} 4^{+} \mathrm{CXCR}^{+} \mathrm{CCR} 7^{\text {low }} \mathrm{PD}- \\
1^{\text {high }} \mathrm{CD} 45 \mathrm{RA}^{-}\end{array}$ & 16.363 & 6.629 & 14.000 & 4.100 & \\
\hline $\begin{array}{l}\text { Takeshita et } \\
\text { al.[26] }\end{array}$ & 2019 & Japan & 53 & 30 & & $\mathrm{CD}^{+} \mathrm{CD}^{+} \mathrm{CXCR}^{+}$ & 13.649 & 4.515 & 11.422 & 4.449 & 7 \\
\hline \multirow[t]{4}{*}{$\begin{array}{l}\text { Wang et al. } \\
\text { [27] }\end{array}$} & 2013 & China & 25 & 15 & a & $\mathrm{CD}^{+} \mathrm{CD}^{+} \mathrm{CXCR}^{+}$ & 15.514 & 6.329 & 11.710 & 4.060 & \multirow[t]{4}{*}{8} \\
\hline & & & & & $b$ & $\mathrm{CD}^{+}{ }^{+} \mathrm{CD} 4^{+} \mathrm{CXCR} 5^{+} \mathrm{PD}-1^{+}$ & 10.603 & 5.382 & 4.783 & 2.173 & \\
\hline & & & & & c & $\mathrm{CD}^{+}{ }^{+} \mathrm{CD} 4^{+} \mathrm{CXCR}^{+} \mathrm{ICOS}^{+}$ & 8.600 & 4.050 & 4.790 & 1.570 & \\
\hline & & & 24 & 15 & d & $\mathrm{CD}^{+}{ }^{\mathrm{CD}} 4^{+} \mathrm{CXCR} 5^{+} \mathrm{PD}-1^{+} \mathrm{ICOS}^{+}$ & 4.646 & 2.554 & 2.713 & 1.496 & \\
\hline \multirow[t]{2}{*}{$\begin{array}{l}\text { Arroyo-Villa } \\
\text { et al. [37] }\end{array}$} & 2014 & Spain & 34 & 34 & a & $\mathrm{CD}^{+} \mathrm{CD}^{+} \mathrm{CXCR}^{+}$ & 16.176 & 6.660 & 16.324 & 7.110 & \multirow[t]{2}{*}{7} \\
\hline & & & & & $b$ & $\mathrm{CD}^{+} \mathrm{CD}^{+}{ }^{+} \mathrm{CXR}^{+} \mathrm{ICOS}^{+}$ & 1.460 & 0.788 & 1.177 & 0.699 & \\
\hline \multirow[t]{3}{*}{ Niu et al. [40] } & 2018 & China & 44 & 20 & a & $\mathrm{CD}^{+}{ }^{\mathrm{CD}} 4^{+} \mathrm{CXCR}^{+} \mathrm{Foxp}^{-}$ & 21.401 & 7.113 & 18.200 & 5.810 & \multirow[t]{3}{*}{7} \\
\hline & & & & & $b$ & $\mathrm{CD}^{+}{ }^{+} \mathrm{CD} 4^{+} \mathrm{CXCR} 5^{+} \mathrm{PD}-1^{+}$ & 28.810 & 11.405 & 13.400 & 3.577 & \\
\hline & & & & & c & $\mathrm{CD}^{+} \mathrm{CD}^{+}{ }^{+} \mathrm{CXR}^{+} \mathrm{ICOS}^{+}$ & 14.238 & 8.115 & 12.300 & 4.470 & \\
\hline Liu et al. [28] & 2012 & China & 47 & 47 & & $\mathrm{CD}^{+} \mathrm{CXCR}^{+} \mathrm{PD}-1^{+}$ & 5.710 & 3.630 & 2.320 & 0.890 & 7 \\
\hline $\begin{array}{l}\text { Cao et al. } \\
\text { [29] }\end{array}$ & 2019 & China & 30 & 30 & & $\mathrm{CD}^{+}{ }^{+} \mathrm{CXCR} 5^{+} \mathrm{PD}-1^{+}$ & 2.610 & 0.970 & 1.350 & 0.450 & 7 \\
\hline $\begin{array}{l}\text { Aldridge et } \\
\text { al. [38] }\end{array}$ & 2018 & Sweden & 75 & 31 & & $\mathrm{CD}^{+} \mathrm{CXCR}^{+} \mathrm{PD}-1^{+}$ & 13.830 & 4.105 & 13.690 & 5.030 & 6 \\
\hline $\begin{array}{l}\text { Wang et al. } \\
\text { [33] }\end{array}$ & 2019 & China & 24 & 20 & & $\mathrm{CD} 4^{+} \mathrm{CXCR} 5^{+} \mathrm{PD}-1^{\text {high }}$ & 4.090 & 3.040 & 0.550 & 0.510 & 7 \\
\hline $\begin{array}{l}\text { Penatti et al. } \\
\text { [44] }\end{array}$ & 2017 & Italy & 8 & 8 & & $\mathrm{CD}^{+} \mathrm{CXCR}^{+} \mathrm{ICOS}^{+}$ & 3.910 & 5.200 & 5.910 & 4.720 & 8 \\
\hline $\begin{array}{l}\text { Zhang et al. } \\
\text { [30] }\end{array}$ & 2015 & China & 54 & 16 & & $\mathrm{CD}^{+} \mathrm{CD} 4^{+} \mathrm{CXCR} 5^{+} \mathrm{ICOS}{ }^{\text {high }}$ & 1.010 & 0.630 & 0.640 & 0.260 & 7 \\
\hline $\begin{array}{l}\text { Nakayamada } \\
\text { et al. [31] }\end{array}$ & 2018 & Japan & 108 & 33 & & $\mathrm{CD}^{+} \mathrm{CD}^{+}{ }^{+} \mathrm{CXR}^{+} \mathrm{ICOS}^{+}$ & 1.100 & 0.500 & 0.900 & 0.400 & 8 \\
\hline \multirow[t]{2}{*}{$\begin{array}{l}\text { Kang et al. } \\
{[41]}\end{array}$} & 2018 & China & 29 & 37 & $a$ & $\mathrm{CD}^{+} \mathrm{CXCR}^{+} \mathrm{CD} 45 \mathrm{RA}^{-}$ & 14.410 & 4.993 & 13.332 & 5.304 & \multirow[t]{2}{*}{6} \\
\hline & & & & & $b$ & $\begin{array}{l}\mathrm{CD} 4^{+} \mathrm{CXCR}^{+} \mathrm{CCR}^{\text {low }} \mathrm{PD}- \\
1^{\text {high }} \mathrm{CD} 45 \mathrm{RA}^{-}\end{array}$ & 5.297 & 3.618 & 3.170 & 2.036 & \\
\hline
\end{tabular}




\begin{tabular}{|c|c|c|c|c|c|c|c|c|c|c|c|}
\hline \multirow[t]{2}{*}{ Author } & \multirow[t]{2}{*}{ Year } & \multirow[t]{2}{*}{ Country } & \multirow{2}{*}{$\begin{array}{l}\text { RA } \\
\text { number }\end{array}$} & \multirow{2}{*}{$\begin{array}{l}\mathrm{HC} \\
\text { number }\end{array}$} & \multirow[t]{2}{*}{ Study } & \multirow[t]{2}{*}{ Tfh definition } & \multicolumn{4}{|c|}{$\%$ of Tfh cells in PB } & \multirow[t]{2}{*}{ NOS } \\
\hline & & & & & & & $\begin{array}{l}\text { RA } \\
\text { mean }\end{array}$ & RA SD & $\begin{array}{l}\mathrm{HC} \\
\text { mean }\end{array}$ & HC SD & \\
\hline $\begin{array}{l}\text { Fukuyo et al. } \\
\text { [34] }\end{array}$ & 2017 & Japan & 34 & 14 & & $\mathrm{CD}^{+}{ }^{+} \mathrm{CXCR}^{+} \mathrm{CD} 45 \mathrm{RA}^{-}$ & 8.970 & 6.600 & 2.010 & 0.200 & 4 \\
\hline \multirow{2}{*}{$\begin{array}{l}\text { Zhou et al. } \\
\text { [42] }\end{array}$} & \multirow[t]{2}{*}{2019} & \multirow[t]{2}{*}{ China } & \multirow[t]{2}{*}{44} & \multirow[t]{2}{*}{37} & a & $\mathrm{CD}^{+} \mathrm{CD}^{+} \mathrm{CXCR}^{+} \mathrm{CD} 45 \mathrm{RA}^{-}$ & 21.102 & 40.720 & 22.677 & 30.590 & \multirow[t]{2}{*}{6} \\
\hline & & & & & $\mathrm{b}$ & $\begin{array}{l}\mathrm{CD}^{+} \mathrm{CDA}^{+} \mathrm{CXCR5^{+ } \mathrm { PD } -} \\
1^{+} \mathrm{ICOS}^{+} \mathrm{CD}^{-} 5 \mathrm{RA}^{-}\end{array}$ & 2.283 & 2.400 & 1.200 & 0.540 & \\
\hline \multirow{3}{*}{$\begin{array}{l}\text { Fortea-Gordo } \\
\text { et al. [43] }\end{array}$} & \multirow[t]{3}{*}{2019} & \multirow[t]{3}{*}{ Spain } & 55 & 47 & a & $\mathrm{CD}^{+} \mathrm{CD}^{+}{ }^{+} \mathrm{CXCR} 5^{+} \mathrm{CD} 45 \mathrm{RA}^{-}$ & 17.365 & 5.970 & 15.735 & 5.278 & \multirow[t]{3}{*}{7} \\
\hline & & & 56 & 47 & $\mathrm{~b}$ & $\begin{array}{l}\mathrm{CD}^{+} \mathrm{CD} 4^{+} \mathrm{CXCR}^{+} \mathrm{PD}- \\
1^{\text {high }} \mathrm{CD}^{-} 5 \mathrm{RA}^{-}\end{array}$ & 0.498 & 0.360 & 0.232 & 0.139 & \\
\hline & & & 55 & 47 & c & $\begin{array}{l}\mathrm{CD3}^{+} \mathrm{CD}^{+} \mathrm{CXCR}^{+} \mathrm{PD}- \\
1^{\text {high }} \mathrm{ICOS}^{+} \mathrm{CD}^{-} 5 \mathrm{RA}^{-}\end{array}$ & 1.008 & 0.660 & 0.529 & 0.405 & \\
\hline $\begin{array}{l}\text { Umeda et al. } \\
\text { [39] }\end{array}$ & 2018 & Japan & 9 & 9 & & $\begin{array}{l}\mathrm{CD} 4^{+} \mathrm{CXCR}^{\text {high }}{ } \mathrm{COS}^{\text {high }} \mathrm{PD}- \\
1^{\text {high }} \mathrm{CD} 45 \mathrm{RA}^{-}\end{array}$ & 10.149 & 9.353 & 10.547 & 6.965 & 5 \\
\hline $\begin{array}{l}\text { Chen et al. } \\
\text { [32] }\end{array}$ & 2016 & China & 41 & 32 & & $\begin{array}{l}\mathrm{CD}^{+}{ }^{+} \mathrm{CD}^{+}{ }^{\text {high }} \mathrm{CXR} 5^{+} \mathrm{CCR} 7^{\text {low }} \mathrm{PD}- \\
{ }^{-}\end{array}$ & 12.800 & 5.700 & 8.700 & 2.000 & 7 \\
\hline $\begin{array}{l}\text { Singh et al } \\
\text { [45] }\end{array}$ & 2016 & USA & 51 & 10 & & $\mathrm{CD}^{+}{ }^{+} \mathrm{CXR} 5^{+} \mathrm{CD} 45 \mathrm{RO}^{+}$ & 23.927 & 8.882 & 27.734 & 13.413 & 8 \\
\hline
\end{tabular}

\subsubsection{Subgroup analysis}

In the next step, we performed subgroup meta-analysis based of different definition markers used for Tfh cells. It should be noted that as all Tfh cells express $\mathrm{CD} 3$ and due to previous antigen exposure all are $C D 45 \mathrm{~A}^{-}$and $C D 45 R O^{+}$memory $T$ cells. Therefore, $C D 3$ and CD45RA/RO were not taken into consideration for subgrouping and meta-analysis. The results of the subgroup analysis based on Tfh definitions are summarized in Table 2.

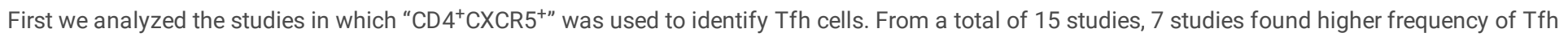
cells in BP of patients with RA compared to HCs [22-27, 34], 7 studies showed no difference [35-37, 40-43], and 1 study reported non-significant decrease in proportion of Tfh cells in RA group [45]. Analysis of the pooled effect size of the 15 studies revealed that RA patients had a significant increased Tfh cells proportion in comparison with the HC group when Tfh cell was defined as "CD $4^{+} C X C R 5^{+"}$ (SMD 0.6, $[0.23,0.96], p=0.001 ;\left.\right|^{2}=86.23 \%$, $p<0.0001$ ) (Supplementary Fig. 1). Funnel plot (Supplementary Fig. 2) and Egger's test detected existence of publication bias $(p=0.015)$. However, when the trim and fill test was applied the result did not change, demonstrating that our results was steady. Then we evaluated the proportion of Tfh cells when

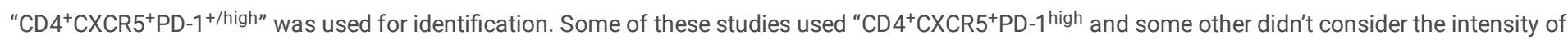
PD-1 expression for definition of Tfh. Of 6 studies, 5 studies revealed the higher proportion of "CD4 ${ }^{+}$CXCR5 ${ }^{+}$PD- $1^{+ \text {" }}$ Tfh cells in RA patients $[25,27-29,40]$ and only 1 study [38] showed no differences. Expectedly, the result of meta-analysis showed higher Tfh cells proportion in RA patients when they defined as "CD4 ${ }^{+} \mathrm{CXCR5}^{+} \mathrm{PD}-1^{+"}$ (SMD 1.18, $\left.[0.67,1.69], \mathrm{p}<0.0001, \mathrm{I}^{2}=81.4 \%, \mathrm{p}<0.0001\right)$ (Supplementary Fig. 3). There was also a significant rise in the proportion of Tfh cells when they were defined as "CD4 ${ }^{+} C X C R 5^{+} P D-1$ high" (SMD 1.22, $[0.95,1.5], p<0.0001, I^{2}=43.80, p=0.168$ ) (Supplementary Fig. 4).

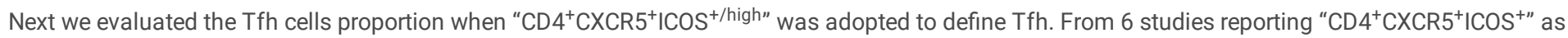
Tfh cells, 3 found higher frequency of Tfh cells in RA [25, 27, 31], while 2 studies showed no difference [37, 40] and 1 reminder revealed non-significant decrease in RA patients [44]. The meta-analysis result of the Tfh cells proportion when they were defined as " $\mathrm{CD} 4^{+} \mathrm{CXCR5^{+ }}$ ICOS ${ }^{+"}$ revealed higher proportion of Tfh cells in PB of RA patients compared to the HCs (SMD 0.54, $[0.13,0.95], p=0.0094, I^{2}=68.66 \%, p=0.0 .013$ ) (Supplementary Fig. 5). In

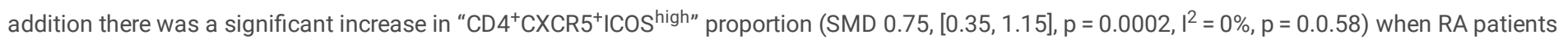
were compared to the HCs (Supplementary Fig. 6).

We also analyzed the studies in which the "CD4 ${ }^{+} \mathrm{CXCR} 5^{+"}$ Tfh cells co-expressed PD- 1 and ICOS (CD4 ${ }^{+}$CXCR5 ${ }^{+}$PD- $1^{+}$ICOS ${ }^{+}$cells). From 4 studies we removed two studies in which high expression of PD-1 and/or ICOS were used for Tfh cell evaluation. According to the pooled SMD result a significant increase in the proportion of Tfh cells co-expressing ICOS and PD-1 was found in RA patients in comparison with the HCs (SMD 0.67, [0.31, 1.04], p = $0.0003, I^{2}=0 \%, p=0.518$ ) (Supplementary Fig. 7).

Finally, we assessed Tfh cells proportion from the studies in which "CD4+CXCR5+CCR7lowPD- $1^{\text {high" }}$ was used to identify Tfh. Of these studies 2 reported markedly higher proportion of Tfh cells in patients with RA [32, 41], and 1 reported no difference when RA group was compared with HC group [36]. Our 
subgroup meta-analysis revealed significant increase in the proportion of "CD $4^{+} C X C R 5^{+} C C R 7^{\text {low } P D-1}$ high" cells in PB of RA patients in comparison with HCs (SMD 0.68, [0.4, 0.96], $\mathrm{p}<0.0001, \mathrm{I}^{2}=4.93 \%, \mathrm{p}=0.34$ ) (Supplementary Fig. 8).

Table 2

Subgroup analysis results of the proportion of Tfh cells in RA compared to HC based on definition markers.

\begin{tabular}{|c|c|c|c|c|c|c|c|}
\hline \multirow[t]{2}{*}{ Tfh definition } & \multirow[t]{2}{*}{ No. } & \multirow[t]{2}{*}{ SMD $[95 \% \mathrm{Cl}]$} & \multirow[t]{2}{*}{$p$} & \multicolumn{2}{|c|}{ Heterogeneity } & \multirow[t]{2}{*}{ Publication bias (Egger's P) } & \multirow[t]{2}{*}{ Model } \\
\hline & & & & $\mathrm{I}^{2}(\%)$ & $\mathbf{p}$ & & \\
\hline $\mathrm{CD} 4^{+} \mathrm{CXCR} 5^{+}$ & 15 & $0.6[0.23,0.96]$ & 0.001 & 86.23 & $p<0.0001$ & 0.015 & REM \\
\hline $\mathrm{CD}^{+}{ }^{+} \mathrm{CXCR}^{+} \mathrm{PD}-1^{+}$ & 6 & $1.18[0.67,1.69]$ & $p<0.0001$ & 81.4 & $p<0.0001$ & 0.088 & REM \\
\hline $\mathrm{CD} 4^{+} \mathrm{CXCR}^{+} \mathrm{PD}-1^{\text {high }}$ & 3 & $1.22[0.95,1.5]$ & $p<0.0001$ & 43.80 & 0.168 & 0.197 & FEM \\
\hline $\mathrm{CD}^{+} \mathrm{CXCR}^{+} \mathrm{ICOS}^{+}$ & 6 & $0.54[0.13,0.95]$ & 0.0094 & 68.66 & 0.013 & 0.588 & REM \\
\hline $\mathrm{CD}^{+} \mathrm{CXCR}^{+} \mathrm{ICOS}^{\text {high }}$ & 2 & $0.75[0.35,1.15]$ & 0.0002 & 0 & 0.58 & - & FEM \\
\hline $\mathrm{CD}^{+}{ }^{+} \mathrm{CXCR}^{+} \mathrm{PD}^{-} 1^{+} \mathrm{ICOS}^{+}$ & 2 & $0.67[0.31,1.04]$ & 0.0003 & 0 & 0.518 & - & FEM \\
\hline $\mathrm{CD} 4^{+} \mathrm{CXCR}^{+} \mathrm{CCR} 7^{\text {low }} \mathrm{PD}-1^{\text {high }}$ & 3 & $0.68[0.4,0.96]$ & $p<0.0001$ & 4.93 & 0.34 & 0.672 & FEM \\
\hline
\end{tabular}

\subsection{The proportion of Tfh in PB of untreated-RA patients as compared with HC}

Studies in which patients were taking steroids or immune-suppressive drugs were removed from this part of the meta-analysis, since treatments were not uniform across the studies. A total of 12 articles covering 21 studies evaluated the proportion of Tfh cells in patients who did not take any medicine at the time of sample collection. Of these, some of studies included patients who didn't receive any drug for at least 1 month [22], 2 months [30, 35] and 3 months [32, 36, 42] before blood sample collection, and 6 articles covering 12 studies included patients with lack of any treatment history [23, 26, 27, 29, $38,43]$. Therefore, the proportion of Tfh cells was compared between RA patients without immunosuppressive treatments and HCs. Pooled analysis without considering the defined phenotypes for Tfh cells revealed a significant higher Tfh cells proportion in u-RA compared to the HC subjects (SMD $0.71,[0.51,0.90], p<0.0001, l^{2}=69.52, p<0.0001$ ) (Fig. 3). Egger's test also showed no publication bias $(p=0.08)$. Furthermore, we performed subgroup

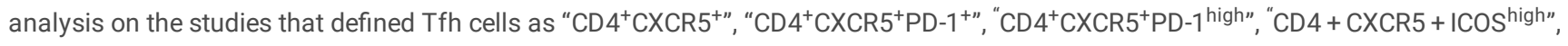

"CD $4^{+} \mathrm{CXCR} 5^{+} \mathrm{PD}-1^{+} \mathrm{ICOS}{ }^{+"}$ and "CD4 ${ }^{+} \mathrm{CXCR} 5^{+} \mathrm{CCR} 7^{\text {low } P D-1}$ high" (Supplementary Fig. 9A-F). As there was a maximum of 1 study per group for other definitions, we couldn't perform subgroup analysis for them. The meta-analysis results revealed a markedly greater proportion of Tfh cells in u-RA compared to $\mathrm{HC}$ individuals when Tfh cells were defined by the 4 out of 5 definitions. (for "CD $4^{+} C X C R 5^{+\prime}:\left(S M D 0.45,[0.18,0.72], p=0.001, I^{2}=60.48, p=\right.$ 0.012; for "CD4 ${ }^{+} C X C R 5^{+} P D-1$ high": SMD 1.17, [0.69, 1.66], $p<0.0001,\left.\right|^{2}=61.26 \%, p=0.108$ ); for "CD $4^{+} C X C R 5^{+} P D-1^{+} I C O S^{+”}$ SMD $0.67,[0.31,1.04], p=$

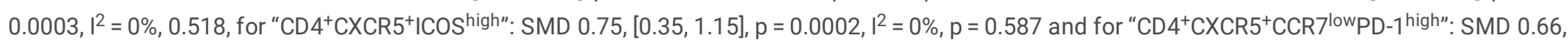
$[0.18,1.14], p=0.0075, I^{2}=50.79 \%, p=0.154$. While "CD $4^{+} C X C R 5^{+} P D-1^{+"}$ cells didn't statistically significant difference, but it has a trend toward significant (SMD 0.96, [-0.02, 1.94], $p=0.055, \mathrm{I}^{2}=89.48, \mathrm{p}<0.0001$ ) (Table 3, Supplementary Fig. 9A-F). In addition, based on Egger's test, no evidence of publication bias was found for the studies $(p>0.1$, Table 3$)$

Table 3

Subgroup analysis results of Tfh cells proportion in u-RA compared to HC based on definition markers.

\begin{tabular}{|c|c|c|c|c|c|c|c|}
\hline \multirow[t]{2}{*}{ Tfh definition } & \multirow[t]{2}{*}{ No. } & \multirow[t]{2}{*}{ SMD $[95 \% \mathrm{Cl}]$} & \multirow[t]{2}{*}{ p } & \multicolumn{2}{|c|}{ Heterogeneity } & \multirow[t]{2}{*}{ Publication bias (Egger's p) } & \multirow[t]{2}{*}{ Model } \\
\hline & & & & $\mathrm{P}^{2}(\%)$ & $\mathbf{p}$ & & \\
\hline $\mathrm{CD}^{+} \mathrm{CXCR}^{+}$ & 8 & $0.45[0.18,0.72]$ & 0.001 & 60.48 & 0.012 & 0.524 & REM \\
\hline $\mathrm{CD}^{+} \mathrm{CXCR}^{+} \mathrm{PD}-1^{+}$ & 3 & $0.96[-0.02,1.94]$ & 0.055 & 89.48 & $\mathrm{p}<0.0001$ & 0.145 & REM \\
\hline $\mathrm{CD} 4^{+} \mathrm{CXCR}^{+} \mathrm{PD}-1^{\text {high }}$ & 2 & $1.17[0.69,1.66]$ & $p<0.0001$ & 61.26 & 0.108 & - & REM \\
\hline $\mathrm{CD}^{+} \mathrm{CXCR}^{+} \mathrm{ICOS}^{\text {high }}$ & 2 & $0.75[0.35,1.15]$ & 0.0002 & 0 & 0.587 & - & FEM \\
\hline $\mathrm{CD}^{+}{ }^{+} \mathrm{CXCR}^{+} \mathrm{PD}-1^{+} \mathrm{ICOS}^{+}$ & 2 & $0.67[0.31,1.04]$ & 0.0003 & 0 & 0.518 & - & FEM \\
\hline $\mathrm{CD} 4^{+} \mathrm{CXCR} 5^{+} \mathrm{CCR} 7^{\text {low }} \mathrm{PD}-1^{\text {high }}$ & 2 & $0.66[0.18,1.14]$ & 0.0075 & 50.79 & 0.154 & - & REM \\
\hline
\end{tabular}

\subsection{The proportion of Tfh cells in PB of early RA compared with HC}


Then we questioned whether the proportion of Tfh would differ between patients and HCs when the stage of the disease course was taken into consideration. We included 3 articles $[27,29,43]$ covering 8 studies in which patients had disease duration less than 6 months as e-RA. All the eRA patients in these studies were treatment naïve with lake of any history of taking immunosuppressive drug. Pooled result regardless of Tfh definition showed that the proportion of Tfh cells in the untreated e-RA patients was significantly higher than that in healthy subjects (SMD 0.92, [0.62, 1.22], $<<$ $0.0001, I^{2}=60.26 \%, p=0.012$ ) (Fig. 4). The egger's test indicated no evidence of publication bias $(p=0.178)$. Subgroup analysis on "CD $4^{+} C X C R 5^{+\prime}$ and "CD ${ }^{+} \mathrm{CXCR}^{+} \mathrm{PD}-1^{+ \text {" }}$ also showed higher proportion of Tfh cells in untreated e-RA compared to HCs by the all three phenotypes (SMD 0.39, [0.05, 0.72$], \mathrm{p}$ $=0.0225, \mathrm{I}^{2}=0 \%, \mathrm{p}=0.322$ for “CD $4^{+} \mathrm{CXCR}^{+"}$; SMD 1.49, $[1.05,1.93], \mathrm{p}<0.0001, \mathrm{I}^{2}=0 \%, \mathrm{p}=0.419$ for “CD $4^{+} \mathrm{CXCR} 5^{+} \mathrm{PD}-1^{+}$") $($Table 4, Supplementary Fig. 10A, B)

Table 4

Subgroup analysis results of Tfh cells proportion in early RA (e-RA) patients compared to HCs based on definition markers.

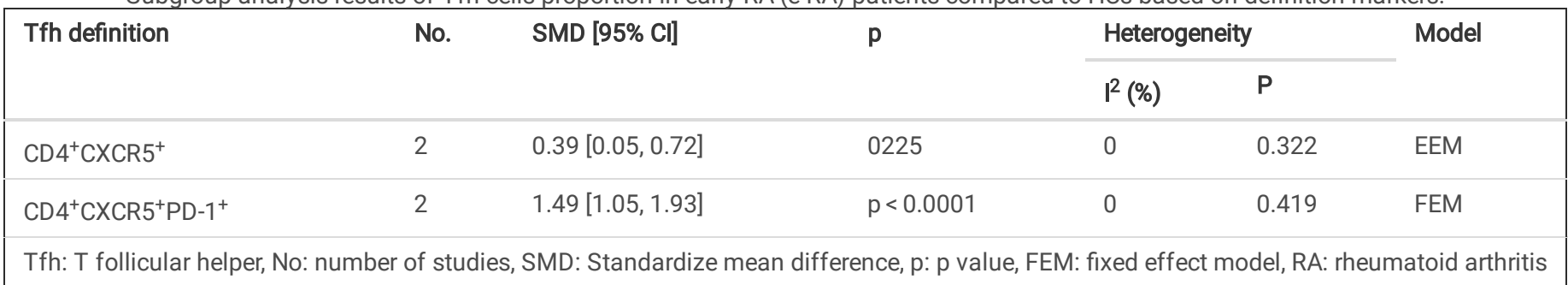

\subsection{The proportion of Tfh in the PB of patients with active RA, patients in remission, and HCs}

We next asked whether the proportion of Tfh cells of the blood CD4 ${ }^{+} T$ cells, could be different between patients with active RA (a-RA) and those who were in remission (r-RA). Eight studies compared the proportion of Tfh cells between a-RA and r-RA, from which 4 studies reported higher proportion of Tfh in aRA, 3 studies reported no differences in the Tfh cells proportion between the two groups, and 1 study reported higher Tfh cells proportion in r-RA (Table 5). The pooled SMD result of Tfh proportion regardless of its definition revealed that there was a significantly higher Tfh cells proportion in the PB of a-RA in comparison with r-RA (SMD 0.27, [0.07, 0.48], $p=0.007, \mathrm{I}^{2}=48.83 \%, \mathrm{p}=0.057$ ) (Fig. 5.A). No risk of publication bias was found based on the egger's test $(p=0.085)$. As evident from Table 5, different set of markers was used by the authors to evaluate the Tfh cells proportion. Thus, we also did sub-group meta-analysis on these studies to compare a-RA with r-RA. Two studies used "CD $4^{+} C X C R 5^{+\prime}$ [22, 37] and 2 used "CD $4^{+} \mathrm{CXCR} 5^{+}$ICOS ${ }^{+\prime}$ [37, 40]. Four

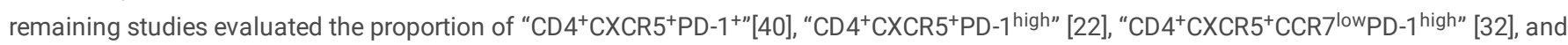
"CD4 ${ }^{+} \mathrm{CXCR} 5^{+} \mathrm{Foxp}^{-"}[40]$ cells, and because meta-analysis could not be performed on only one study, they were removed from sub-analysis. The subgroup meta-analysis results revealed no difference between a-RA and r-RA when Tfh cells were defined by the two above-mentioned markers (for

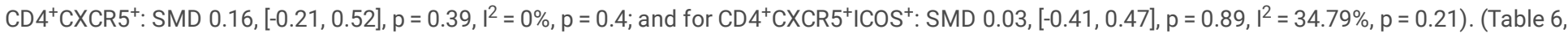
supplementary Fig. 11A, B)

We also performed the same analysis to compare a-RA patients with $\mathrm{HC}$ group. Total of 8 studies compared the proportion of Tfh cells between a-RA and $\mathrm{HC}$ groups. Of these, 6 studies showed significant increase in the Tfh cells proportion in a-RA, and 2 remaining studies showed no differences (Table 5). Pooled meta-analysis result regardless of the Tfh definition revealed significant increase in the PB Tfh cell proportion when a-RA patients were compared to HCs (SMD 0.91, [0.4, 1.42], $\left.p=0.0004, I^{2}=83.4 \%, p<0.0001\right)$. Furthermore, egger's test indicated that there was no publication bias $(p=0.1)$. Next, we analyzed sub-group meta-analysis based on different definition markers used for Tfh cells. Of the 8 studies, two used "CD $4^{+} C X C R 5^{+\prime}$ and 2 used CD $4+$ $\mathrm{CXCR} 5+\mathrm{ICOS}^{+}$to define Tfh cells. Pooled analysis for both definitions demonstrated no differences in the proportion Tfh cells between a-RA and HCs.

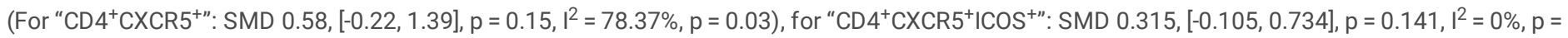
0.72) (Table 6, supplementary Fig. 12A, B) 
Table 5

Characteristics of the studies that compared the proportion of Tfh cells in active- and remission-RA with HCs.

\begin{tabular}{|c|c|c|c|c|c|c|c|c|c|c|c|c|}
\hline \multirow[t]{2}{*}{ Author } & \multirow[t]{2}{*}{ Year } & \multirow[t]{2}{*}{ Country } & \multirow{2}{*}{$\begin{array}{l}\text { a-RA } \\
\text { number }\end{array}$} & \multirow{2}{*}{$\begin{array}{l}\text { r-RA } \\
\text { number }\end{array}$} & \multirow{2}{*}{$\begin{array}{l}\mathrm{HC} \\
\text { number }\end{array}$} & \multirow[t]{2}{*}{ Tfh definition } & \multicolumn{2}{|l|}{$a-R A$} & \multicolumn{2}{|l|}{ r-RA } & \multicolumn{2}{|l|}{$\mathrm{HC}$} \\
\hline & & & & & & & mean & SD & mean & SD & mean & SD \\
\hline $\begin{array}{l}\text { Liu et } \\
\text { al. a }\end{array}$ & 2018 & China & 39 & 39 & 33 & $\mathrm{CD}^{+}{ }^{+} \mathrm{CXCR} 5^{+}$ & 19.000 & 3.540 & 18.810 & 3.170 & 15.18 & 4.19 \\
\hline $\begin{array}{l}\text { Liu et } \\
\text { al. } \beta\end{array}$ & 2018 & China & 39 & 39 & 33 & $\mathrm{CD} 4^{+} \mathrm{CXCR} 5^{+} \mathrm{PD}-1^{\text {high }}$ & 7.110 & 2.860 & 7.030 & 2.750 & 3.59 & 1.01 \\
\hline $\begin{array}{l}\text { Arroyo- } \\
\text { Villa et } \\
\text { al. a }\end{array}$ & 2014 & Spain & 17 & 17 & 34 & $\mathrm{CD}^{+} \mathrm{CD}^{+} \mathrm{CXCR}^{+}$ & 17.511 & 8.189 & 14.840 & 4.673 & 16.32 & 7.11 \\
\hline $\begin{array}{l}\text { Arroyo- } \\
\text { Villa et } \\
\text { al. } \beta\end{array}$ & 2014 & Spain & 17 & 17 & 34 & $\mathrm{CD}^{+}{ }^{\mathrm{CD}} 4^{+} \mathrm{CXCR}^{+} \mathrm{ICOS}^{+}$ & 1.345 & 0.638 & 1.574 & 0.929 & 1.18 & 0.70 \\
\hline $\begin{array}{l}\text { Niu et } \\
\text { al. a }\end{array}$ & 2018 & China & 20 & 24 & 20 & $\mathrm{CD}^{+}{ }^{\mathrm{CD}} 4^{+} \mathrm{CXCR} 5^{+} \mathrm{Foxp}^{-}$ & 25.000 & 7.155 & 18.400 & 5.388 & 18.2 & 5.81 \\
\hline $\begin{array}{l}\text { Niu et } \\
\text { al. } \beta\end{array}$ & 2018 & China & 20 & 24 & 20 & $\mathrm{CD}^{+}{ }^{+} \mathrm{CD} 4^{+} \mathrm{CXCR} 5^{+} \mathrm{PD}-1^{+}$ & 31.500 & 9.390 & 26.500 & 12.240 & 13.4 & 3.577 \\
\hline $\begin{array}{l}\text { Niu et } \\
\text { al. Y }\end{array}$ & 2018 & China & 20 & 24 & 20 & $\mathrm{CD}^{+}{ }^{\mathrm{CD}} 4^{+} \mathrm{CXCR}^{+} \mathrm{ICOS}^{+}$ & 15.500 & 10.280 & 13.200 & 5.870 & 12.3 & 4.47 \\
\hline $\begin{array}{l}\text { Chen } \\
\text { et al. }\end{array}$ & 2016 & China & 35 & 6 & - & $\begin{array}{l}\mathrm{CD}^{+} \mathrm{CD} 4+ \\
\mathrm{CXCR}^{+}{ }^{+} \mathrm{C} C \mathrm{R} 7^{\text {low }} \mathrm{PD}-1^{\text {high }}\end{array}$ & 13.339 & 5.867 & 7.720 & 2.466 & - & - \\
\hline $\begin{array}{l}\text { Zhang } \\
\text { et al. }\end{array}$ & 2015 & China & 54 & - & 16 & $\begin{array}{l}\mathrm{CD}^{+}{ }^{+} \mathrm{CD} 4^{+} \mathrm{CXCR} 5^{+} \mathrm{ICOS} \\
\text { high }\end{array}$ & 1.01 & 0.63 & - & - & 0.64 & 0.26 \\
\hline
\end{tabular}

Table 6

Subgroup analysis results of disease activity status and Tfh cell proportions.

\begin{tabular}{|c|c|c|c|c|c|c|c|}
\hline \multirow[t]{2}{*}{ Groups } & \multirow[t]{2}{*}{ Tfh definition } & \multirow[t]{2}{*}{ No. } & \multirow[t]{2}{*}{ SMD $[95 \% \mathrm{Cl}]$} & \multirow[t]{2}{*}{$\mathbf{p}$} & \multicolumn{2}{|c|}{ Heterogeneity } & \multirow[t]{2}{*}{ Model } \\
\hline & & & & & $\left.\right|^{2}(\%)$ & $p$ & \\
\hline \multirow[t]{2}{*}{ a-RA vs r-RA } & $\mathrm{CD}^{+}{ }^{+} \mathrm{CXCR} 5^{+}$ & 2 & $0.16[-0.21,0.52]$ & 0.39 & 0 & 0.4 & FEM \\
\hline & $\mathrm{CD}^{+}{ }^{+} \mathrm{CXR}^{+} \mathrm{ICOS}^{+}$ & 2 & $0.03,[-0.41,0.47]$ & 0.89 & 34.79 & 0.21 & FEM \\
\hline \multirow[t]{2}{*}{ a-RA vs HC } & $\mathrm{CD}^{+} \mathrm{CXCR}^{+}$ & 2 & $0.58[-0.22,1.39]$ & 0.15 & 78.37 & 0.03 & REM \\
\hline & $\mathrm{CD}^{+} \mathrm{CXCR}^{+} \mathrm{ICOS}^{+}$ & 2 & $0.315[-0.105,0.734]$ & 0.141 & 0 & 0.72 & FEM \\
\hline
\end{tabular}

Tfh: T follicular helper, No: number of studies, SMD: Standardize mean difference, p: p value, REM: random effect model, FEM: fixed effect model, aRA: active rheumatoid arthritis, r-RA: remission rheumatoid arthritis, HC: healthy control

\subsection{The proportion of Tfh in PB of seropositive RA patients versus seronegative RA patients and HCs}

Seropositive patients were defined as anti-citrullinated protein antibodies (ACPA) ${ }^{+}$and/or rheumatoid factor (RF) ${ }^{+}$. Whether Tfh cells proportion among $\mathrm{PB} \mathrm{CD} 4^{+} \mathrm{T}$ cells is different between $\mathrm{S}^{+} \mathrm{RA}$ and $\mathrm{S}^{-} \mathrm{RA}$ patients was evaluated. Five studies assessed the proportion of Tfh in $\mathrm{S}^{+} \mathrm{RA}$ compared with $\mathrm{S}^{-} \mathrm{RA}$ patients, of which 3 studies showed higher proportion of Tfh in $\mathrm{S}^{+} \mathrm{RA}$, and 2 other showed no difference (Table 7). Pooled meta-analysis of all 5 studies, regardless of the Tfh definition revealed a significant increase in the proportion of Tfh cells in PB of patients with $\mathrm{S}+\mathrm{RAcompared}$ to that of those with $S^{-} \operatorname{RA}\left(S M D 0.64,[0.36,0.91], p<0.0001,\left.\right|^{2}=3.85 \%, p=0.38\right.$ ) (Fig. 6A). In addition, based on the egger's test, no publication bias was found ( $\left.p=0.82\right)$. It should be noted that 4 out of the 5 studies were evaluated Tfh cells proportion in "early RA" patients. In addition, since only two studies used the same pattern of Tfh definition (CD $4^{+}$CXCR5 $\left.{ }^{+} \mathrm{PD}-1^{\text {high }}\right)$ to compare $\mathrm{S}^{+} \mathrm{RA}$ and $\mathrm{S}^{-} \mathrm{RA}$ patients, we performed a sub-group meta-analysis on these studies. The sub-analysis revealed higher proportion of Tfh cells in PB of $\mathrm{S}^{+}$RA compared with S ${ }^{-}$RA patients when Tfh was defined as "CD $4^{+} C X C R 5^{+} P D-1^{\text {high" }}$ (SMD $0.67,[0.26,1.07], p=0.001,\left.\right|^{2}=0 \%, p=0.93$ ) (Table 8, supplementary Fig. 13).

We then performed further analyses to compare the proportion of PB Tfh cells between $\mathrm{S}^{+} \mathrm{RA}$ patients and the HCs. Four studies from one article were evaluated PB Tfh proportion in $\mathrm{S}^{+} \mathrm{RA}$ and HCs with different definitions. Pooled SMD result revealed that the proportion of Tfh cells was markedly higher in PB of $S^{+}$RA patients compared to HCs (SMD 0.89, [0.48, 1.3], $\left.p<0.0001, l^{2}=68.92 \%, p=0.019\right)$ (Fig. 6.B). Egger's tests indicated no publication bias ( $p$ 
= 0.178). In addition two studies from this article compared the proportion of "CD $4^{+} C X C R 5^{+} P D-1^{\text {high" }}$ Tfh cells between early RA or established RA and $\mathrm{HCs}$. Subgroup analysis of the proportion of "CD4 ${ }^{+} \mathrm{CXCR} 5^{+} \mathrm{PD}-1^{\text {high" }}$ cells regardless of the disease stage revealed a significantly higher proportion of Tfh cells in $S^{+}$RA compared with HCs (SMD 1, [0.67, 1.33], $p<0.0001, \mathrm{I}^{2}=34.9 \%, p=0.215$ ). (Table 8, supplementary Fig. 14)

Table 7

Characteristics of the studies that compared Tfh cells proportion between $\mathrm{S}^{+} \mathrm{RA}$ and $\mathrm{S}^{-} \mathrm{RA}$, and $\mathrm{S}^{+} \mathrm{RA}$ and $\mathrm{HCs}$.

\begin{tabular}{|c|c|c|c|c|c|c|c|c|c|c|c|c|}
\hline \multirow[t]{2}{*}{ Author } & \multirow[t]{2}{*}{ Year } & \multirow[t]{2}{*}{ Country } & \multirow{2}{*}{$\begin{array}{l}\mathrm{S}^{+} \mathrm{RA} \\
\text { number }\end{array}$} & \multirow{2}{*}{$\begin{array}{l}\mathrm{S}^{-} \mathrm{RA} \\
\text { number }\end{array}$} & \multirow{2}{*}{$\begin{array}{l}\mathrm{HC} \\
\text { number }\end{array}$} & \multirow[t]{2}{*}{ Tfh definition } & \multicolumn{2}{|l|}{$\mathrm{S}^{+} \mathrm{RA}$} & \multicolumn{2}{|l|}{$S^{-} R A$} & \multicolumn{2}{|l|}{$\mathrm{HC}$} \\
\hline & & & & & & & mean & SD & mean & SD & mean & SD \\
\hline $\begin{array}{l}\text { Ma et } \\
\text { al. }\end{array}$ & 2012 & China & 19 & 6 & - & $\mathrm{CD} 4^{+} \mathrm{CXCR} 5^{+} \mathrm{ICOS}^{\text {high }}$ & 0.197 & 0.209 & 0.074 & 0.051 & - & - \\
\hline $\begin{array}{l}\text { Fortea- } \\
\text { Gordo } \\
\text { et al. } \\
\text { (a) }\end{array}$ & 2019 & Spain & 38 & 17 & 47 & $\mathrm{CD}^{+}{ }^{+} \mathrm{CD} 4^{+} \mathrm{CXCR}^{+} \mathrm{CD} 45 \mathrm{RA}^{-}$ & 17.748 & 5.587 & 16.510 & 6.868 & 15.735 & 5.278 \\
\hline $\begin{array}{l}\text { Fortea- } \\
\text { Gordo } \\
\text { et al. } \\
(\beta)\end{array}$ & 2019 & Spain & 38 & 18 & 47 & $\begin{array}{l}\mathrm{CD}^{+}{ }^{+} \mathrm{CD} 4^{+} \mathrm{CXCR}^{+} \mathrm{PD}-1^{\text {high }} \\
\mathrm{CD} 45 \mathrm{RA}^{-}\end{array}$ & 0.574 & 0.393 & 0.337 & 0.276 & 0.232 & 0.139 \\
\hline $\begin{array}{l}\text { Fortea- } \\
\text { Gordo } \\
\text { et al. } \\
(\gamma)\end{array}$ & 2019 & Spain & 38 & 17 & 47 & $\begin{array}{l}\mathrm{CD}^{+} \mathrm{CD} 4^{+} \mathrm{CXCR} 5^{+} \mathrm{PD}- \\
1^{\text {high }_{1} \mathrm{ICOS}^{+} \mathrm{CD} 45 \mathrm{RA}^{-}}\end{array}$ & 1.207 & 0.674 & 0.562 & 0.394 & 0.529 & 0.404 \\
\hline $\begin{array}{l}\text { Fortea- } \\
\text { Gordo } \\
\text { et al. } \\
(\delta)\end{array}$ & 2019 & Spain & 47 & - & 29 & $\begin{array}{l}\mathrm{CD}^{+}{ }^{\mathrm{CD}} 4^{+} \mathrm{CXCR} 5^{+} \mathrm{PD}-1^{\text {high }} \\
\mathrm{CD} 45 \mathrm{RA}^{-}\end{array}$ & 0.271 & 0.177 & - & - & 0.151 & 0.095 \\
\hline $\begin{array}{l}\text { A. Rao } \\
\text { et al. } \\
\text { [46] }\end{array}$ & 2017 & USA & 42 & 16 & - & $\begin{array}{l}\mathrm{CD}^{+} \mathrm{CD} 4^{+} \mathrm{CXCR}^{+} \mathrm{PD}- \\
1^{\text {high }} \mathrm{CD} 45 \mathrm{RA}^{-}\end{array}$ & 0.625 & 0.500 & 0.316 & 0.250 & - & - \\
\hline
\end{tabular}

Table 8

Subgroup analysis results based on serostatus and Tfh cell proportions.

\begin{tabular}{|c|c|c|c|c|c|c|c|}
\hline \multirow[t]{2}{*}{ Groups } & \multirow[t]{2}{*}{ Tfh definition } & \multirow[t]{2}{*}{ No. } & \multirow[t]{2}{*}{ SMD $[95 \% \mathrm{Cl}]$} & \multirow[t]{2}{*}{$\mathrm{p}$} & \multicolumn{2}{|c|}{ Heterogeneity } & \multirow[t]{2}{*}{ Model } \\
\hline & & & & & $\mathrm{I}^{2}(\%)$ & $\mathbf{p}$ & \\
\hline$S^{+} R A$ vs $S^{-} R A$ & $\mathrm{CD} 4^{+} \mathrm{CXCR} 5^{+} \mathrm{PD}-1^{\text {high }}$ & 2 & $0.67[0.26,1.07]$ & 0.001 & 0 & 0.93 & FEM \\
\hline $\mathrm{S}^{+} \mathrm{RA}$ vs HC & $\mathrm{CD} 4^{+} \mathrm{CXCR} 5^{+} \mathrm{PD}-1^{\text {high }}$ & 2 & $1[0.67,1.33]$ & $p<0.0001$ & 34.9 & 0.215 & FEM \\
\hline
\end{tabular}

\subsection{Geographic location of studies and Tfh cells proportion in PB of RA patients}

Finally, we assessed the proportion of Tfh cells based on the geographical regions where the studies were performed. Regarding the geographic location of the included studies 14 studies were performed in China, 4 in Japan, 2 in Spain, 1 in Sweden, 1 in Italy, 1 in USA, and 1 in Argentina (Table 1 ) to compare RA with HC. We divided the studies into 2 groups, Asian and non-Asian studies. There were 18 articles covering 30 studies on Asian populations (Japan and China), and 6 articles covering 9 studies on the non-Asians (Table 1). The pooled SMD revealed that there was higher Tfh cells proportion in RA patients compared to HCs in Asian populations (SMD 0.89, $[0.68,1.09], p<0.0001, I^{2}=77.48, p<0.0001$ ) (Supplementary Fig. 15), while surprisingly there was no significant difference in the proportion of Tfh between the two groups in non-Asians (SMD 0.29, $[-0.003,0.59], p=0.052, I^{2}=69.15 \%, p=$ 0.0012) (Supplementary Fig. 16). There was an evidence of publication bias in the Asian analysis based on egger's test ( $p=0.02)$ and funnel plot, and implementing the trim-and-fill method did not show any change in the bias-adjusted result. Regarding non-Asians there was also publication bias ( $p=$ 0.039, Supplementary Fig. 17) and adjustment by trim-and-fill analysis revealed an increase in the pooled SMD.

\section{Discussion}

The main function of Tfh cell is to help B lymphocytes to proliferate, differentiate and promote antibody production, and regulate humoral immunity [5, 6]. When $\mathrm{CD}^{+}$naïve-T cells are activated, they increase CXCR5expression, while decrease CCR7, which allows them to migrate into the B-cell follicles in response to CXCR5 ligand, CXCL13. This enables Tfh to localize in close proximity to and interact with B cell, and promotes GC formation and class switched high affinity antibody production [6, 9]. However, Tfh deregulations can drive abnormal germinal center, B-lymphocyte differentiation and survival, autoantibody generation, and thus could be related to the development of autoimmune diseases [12, 47]. Due to the difficulty in the sampling 
from human lymphoid tissue [6, 8], and since PB Tfh cells in terms of phenotypic and B lymphocyte helper functions are similar to the GC Tfh cells [16], analysis of cTfh cells in patients has become an important clinically significant alternative strategy [48]

RA is a systemic autoimmune disease characterized by the production of a large number of autoantibodies, such as ACPAs, RF and others [3], and this autoantibody production may be related to Tfh cell abnormality. In this line, while several studies have evaluated the frequency of Tfh in the PB of patients with RA compared to HCs, conflicting conclusions have been reached in some cases. The purpose of this work was to systematically evaluate the proportion of Tfh in PB of RA patients compared to HCs to clarify the proportion of cTfh in RA patients.

Meta-analysis of all included studies neglecting the definition markers, treatment status, disease activity status and serological status of the RA patients revealed a significantly higher Tfh cells proportion in the PB of patients with RA in comparison with HCs. However, significantly high degree of heterogeneity was found between studies. Thus, sub-group analyses were subsequently performed based on different factors including surface markers used to define Tfh cells, treatment status, disease activity status, and serological status of the patients as well as the geographical location of the included studies from which the participants originated. Our sub-analyses revealed that subgrouping the studies based on these criteria were associated with reduction in the strength of heterogeneity in most of analyses which reached to moderate, low or even no heterogeneity (Tables $2,3,4,6$ and 8 ).

In the sub-group analyses, at first we performed the meta-analysis based on only definition markers used to identify Tfh cells. According to the results, the proportion of Tfh cells with the all definition markers was significantly higher in the PB of RA patients compared to HCs (Table 2). From different definitions, "CD $4^{+} C X C R 5^{+} P D-1^{\text {high" }}$ and then "CD $4^{+} C X C R 5^{+} P D-1^{+"}$ cells showed the largest SMD, and while "CD $4^{+} C X C R 5^{+"}$ were significantly increased in RA, it showed the lowest SMD, suggesting the importance of considering the expression level of PD-1 in RA patients.

PD-1 can promote GC B cells survival and high-affinity long-lived plasma cell formation through its interaction with programmed death-ligand 1 (PD-L1) and PD-L2 on the surface of GC B cells [49,50]. Studies have shown that the expression of PD-1 is elevated on Tfh cells in patients with autoimmune diseases including RA [40,51], and PD-1 ${ }^{\text {high }}$ Tfh cells have a stronger ability to activate $B$ lymphocytes [51]. Consistently, a positive correlation has been found between the expression of PD-1 on Tfh cells, and disease activity of RA [40]. However, the negative regulatory function of this molecule on T cells, that is essential for maintaining peripheral immune-tolerance, should not be ignored [49,52]. Blocking the interaction of PD-1 with its ligands leads to increase differentiation and number of Tfh cells [50], suggesting the negative regulatory function of PD- 1 signals in the differentiation of Tfh cells. Thus, the expression level of PD-1 could mirror the activation status of the Tfh cells, and the increasing in the expression of PD-1 on Tfh cells in RA patients might represent a spontaneous compensatory regulation mechanisms for controlling its excessive activation. But this regulatory feedback fails to inhibit Tfh cells, which is due to increase in soluble form of PD-1 (sPD-1) in the RA patients [33,53]. Consistently, there is also a significant positive correlation between serum level of the SPD- 1 and the frequency of cTfh cells, titer of auto-antibodies and DAS in RA patients [33, 53]. Indeed, the inhibitory function of the increased membrane-bound PD-1 on Tfh cells is blocked in the presence of its soluble form, while its humoral assistance to antibody producing cells is intact or even hyper activated. The results of our meta-analyses revealed significantly higher proportion of Tfh cells in all the comparisons which have included $\mathrm{PD}-1^{\text {high }}$ for Tfh cells (RA versus $\mathrm{HC}$, $\mathrm{u}$-RA versus $\mathrm{HC}, \mathrm{S}^{+} \mathrm{RA}$ versus $\mathrm{S}^{-} \mathrm{RA}$ and $\mathrm{S}^{+} \mathrm{RA}$ versus $\mathrm{HC}$ ). Furthermore, based on subgroup analyses, the definitions which included PD- 1 ("CD $4^{+} C X C R 5^{+}$PD $-1^{+ \text {" }}$ and especially "CD $4^{+}$CXCR5 ${ }^{+}$PD -1 high") had the largest SMDs in comparison with the other definitions suggesting more associations between the proportion of these phenotypes and RA. Thus, in RA patients, the higher expression of PD-1 on the Tfh cells could be associated with the higher proportion of these cells.

ICOS is another surface molecule that has a pivotal role in the development of Tfh cells and also in the production of IL-21 as signature cytokine of Tfh [54]. In addition, ICOS signaling is essential for maintenance of anatomical localization of Tfh cells in B cell follicles through preserving the expression of homing receptor pattern on Tfh cells. Blocking of ICOS has also been shown to lead to reverse differentiation of Tfh through CCR7 up-regulation and CXCR5 down-regulation, hence relocation of Tfh cells to the T cell zone and subsequently collapsing of the GC response [55, 56]. ICOS also promotes survival and functional maturation of GC B cells [57]. Furthermore, Tfh cells expressing the highest expression level of ICOS have the most capacity of inducing IgG production [58]. Our study demonstrated that Tfh cells expressing ICOS (CD $4^{+} \mathrm{CXCR} 5^{+} \mathrm{ICOS}{ }^{+}$and $\left.\mathrm{CD} 4^{+} \mathrm{CXCR} 5^{+} I \mathrm{ICOS}{ }^{\text {high }}\right)(\mathrm{Table} 2)$ were higher in RA versus HCs. In addition, "CD $4^{+} \mathrm{CXCR} 5^{+}$ICOS high" proportion had higher association with RA than "CD $4^{+} \mathrm{CXCR} 5^{+} \mathrm{ICOS}{ }^{+\prime}$ proportion as was evident from SMDs (Table 2) which, could be justified by the above-mentioned roles defined for ICOS molecule. Considering the importance of ICOS in antibody production, unfortunately there were not at least 2 studies with $C D 4^{+} C X C R 5^{+} I C O S^{+/ h i g h}$ definitions for comparing Tfh cells proportion based on serostatus subgroup analyses.

We also analyzed the studies that only included untreated patients to exclude the effect of immuno-suppressive drugs. The results further confirmed the elevated proportions of Tfh cells in untreated patients, regardless of their definitions. Furthermore, subgroups analyses demonstrated higher proportions

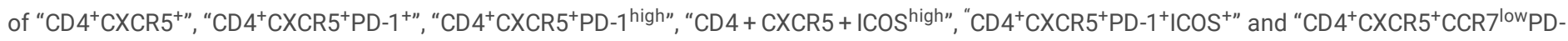
$1^{\text {high" }}$ cells in u-RA compared with HCs. From these comparisons the highest association was found for "CD $4^{+} C X C R 5^{+} P D-1^{\text {high" }}$, and "CD $4^{+} C X C R 5^{+"}$ had the lowest SMD, again suggesting the importance PD-1 molecules in defining the Tfh cells.

The proportion of Tfh cell was also evaluated based on the stage of the disease course. According to 2015 ACR guideline, RA patients with disease duration less than 6 months are considered "early RA", and those with disease duration $\geq 6$ months are considered as "established RA" [59]. Studies have shown that the immunological aberrations during the first few months after the disease onset differ from those during later phases [60], which may explain why response rate to treatment in early RA patients is different from those of established RA (early treatment of the RA patients is beneficial and can improve disease outcome) [61,62]. Because of the importance of the early diagnosis of RA and also to clarify the status of Tfh cell in the early phase of the disease, we also compared Tfh cells proportion in e-RA patients with that of HCs. All e-RA patients included in the selected articles were treatment

Page $11 / 20$ 
naïve. The pooled results of the all Tfh definitions exhibited that cTfh cells proportion in untreated e-RA patients was significantly greater than that of the $\mathrm{HC}$ group. Subgroup analysis of Tfh cells with definitions of "CD $4^{+} \mathrm{CXCR} 5^{+ \text {", }} \mathrm{CD} 4+\mathrm{CXCR} 5+\mathrm{PD}-1^{+}$also showed higher Tfh cells proportion in untreated eRA compared to HCs, suggesting pathogenetic role of Tfh in initial stage of the RA development.

In the next step, Tfh cells proportion in patients with a-RA was compared to r-RA patients and HCs. The pooled results regardless of definition markers revealed that the proportion of Tfh cells in a-RA patients was significantly greater than those of both r-RA patients and HCs. Altogether these results suggest pathogenic association of the Tfh frequency with RA. We then evaluated the Tfh cell proportion based on Tfh definitions. The results revealed that there was no significant difference in the proportion of "CD $4^{+} \mathrm{CXCR} 5^{+}$", and "CD $4^{+} \mathrm{CXCR} 5^{+} \mathrm{ICOS}{ }^{+}$" cells when a-RA was compared to the both r-RA and HCs, though higher SMD was observed for comparison of a-RA versus HCs than the SMD derived from comparing a-RA with r-RA. It should be kept in mind that since a maximum of two studies have been used for sub-meta analyses comparing a-RA with r-RA and HCs, the power of the test is low in these comparisons and meta-analysis on higher number of studies in the future could be more valuable.

To evaluate the link between the frequency of Tfh cells and presence of auto-antibodies in RA, we next performed meta-analysis with respect to the serological status of the patients. $\mathrm{S}^{+} \mathrm{RA}$ is defined as positive for RF or ACPAs. Seropositivity is associated with more severe disease, joint destruction, and even higher mortality [3]. The pooled meta-analysis results, regardless of the Tfh definition demonstrated that $\mathrm{S}^{+} \mathrm{RA}$ patients had a significantly higher proportion of Tfh cells in their PB compared to the either $\mathrm{S}^{-} \mathrm{RA}$ patients or HCs. Also, markers-based subgroup analysis showed that the proportion of Tfh cells was significantly elevated in $\mathrm{S}^{+} \mathrm{RA}$ in comparison with the both $\mathrm{S}^{-} \mathrm{RA}$ patients and HCs when Tfh cells were defined as CD $4^{+} \mathrm{CXCR} 5^{+} \mathrm{PD}-\mathrm{1}^{\text {high }}$. This can further emphasize the previously mentioned importance of PD-1 expression level in the frequency of Tfh cells and autoantibody production in RA patients. Due to insufficient study number, we unfortunately couldn't perform subgroup analysis on the other Tfh definitions especially ICOSexpressing Tfh cells to compare $S^{+} R A$ and $S^{-} R A$ patients. Altogether, these results demonstrate that the production of auto-antibodies in RA patients is associated with the proportion of $\mathrm{CD} 4^{+} \mathrm{CXCR} 5^{+} \mathrm{PD}-1^{\text {high }} \mathrm{Tfh}$ cells, which provides evidence for the connection between the seropositivity and the proportion of these cTfh cells.

Looking at different definitions used in all comparisons demonstrates that the largest SMDs for proportion of Tfh cells in comparison groups belong to the Tfh cells expressing PD- 1 (PD- $1^{+}$and especially PD-1 ${ }^{\text {high }}$ ), while the lowest association was related to the "CD $4^{+} \mathrm{CXCR} 5^{+”}$ cells.

The present work has some limitations. First, as disease duration was inconsistent across the studies we couldn't consider duration of the disease in the analysis. Second, the disease activity score of RA patients was not uniform through the studies. Third, due to heterogeneity of drugs used for treatment of patient, we couldn't evaluate the effect of treatment on the proportion of Tfh cells in RA. Fourth, insufficient number of studies with particular Tfh definitions prevented their evaluation in some of the comparisons.

\section{Conclusions}

In conclusion, this is the first systematic review and meta-analysis that has assessed the proportion of PB Tfh cells in RA patients. Our analyses demonstrate that compared to HCs the proportions of Tfh cells in general, and in particular Tfh cells expressing PD- 1 (PD- $1^{\text {high }}$ and then PD- $1^{+}$) are highly elevated in patients with RA. Therefore, this cell type likely plays a pathogenic role in RA and could potentially be used as biomarker for diagnosis, prognosis, or as a target for treatment.

\section{Declarations}

\section{Author Contributions}

PB: study design. PB, MAH and KK: data collection. PB: statistical analysis. PB: paper writing. KK, KKE, RES, DK, SM: paper review \& editing. All authors approved the submitted version of the manuscript.

\section{Funding}

None.

\section{Competing interests}

None.

\section{Acknowledgements}

None.

Ethics approval: This is an observational study. The Shiraz University of Medical Sciences Research Ethics Committee has confirmed that no ethical approval is required.

\section{Consent for publication}

This is an observational( Meta-Analysis) study and we were not in contact with patients and there was no need to get a consent form from patients. 


\section{References}

1. Guo Q, Wang Y, Xu D, Nossent J, Pavlos NJ, J. Xu. Rheumatoid arthritis: pathological mechanisms and modern pharmacologic therapies. Bone research, 2018;6:1-14.

2. Smolen JS, Aletaha D, Barton A, Burmester GR, Emery P, Firestein GS, et al. Rheumatoid arthritis. Nature Reviews Disease Primers. $2018 ; 4: 18001$.

3. Smolen JS, Aletaha D. I. B. Mclnnes. Rheumatoid arthritis. Lancet. 2016;388:2023-38.

4. Chemin K, Gerstner C, Malmström V. Effector Functions of CD4 + T Cells at the Site of Local Autoimmune Inflammation-Lessons From Rheumatoid Arthritis. Frontiers in Immunology, 2019;10.

5. McHeyzer-Williams LJ, Pelletier N, Mark L, Fazilleau N. M. G. McHeyzer-Williams. Follicular helper T cells as cognate regulators of B cell immunity. Curr Opin Immunol. 2009;21:266-73.

6. Fazilleau N, Mark L, McHeyzer-Williams LJ. M. G. McHeyzer-Williams. Follicular helper T cells: lineage and location. Immunity. 2009;30:324-35.

7. Chtanova T, Tangye SG, Newton R, Frank N, Hodge MR, MS Rolph et al. T Follicular Helper Cells Express a Distinctive Transcriptional Profile, Reflecting Their Role as Non-Th1/Th2 Effector Cells That Provide Help for B Cells. J Immunol. 2004;173:68.

8. Breitfeld D, Ohl L, Kremmer E, Ellwart J, Sallusto F, M Lipp et al. Follicular B helper T cells express CXC chemokine receptor 5, localize to B cell follicles, and support immunoglobulin production. The Journal of experimental medicine. 2000;192:1545-52.

9. Schaerli P, Willimann K, Lang AB, Lipp M, Loetscher P. B. Moser. CXC chemokine receptor 5 expression defines follicular homing T cells with B cell helper function. The Journal of experimental medicine. 2000;192:1553-62.

10. Kim CH, Rott LS, Clark-Lewis I, Campbell DJ, Wu L. E. C. Butcher. Subspecialization of CXCR5 + T cells: B helper activity is focused in a germinal center-localized subset of CXCR5 + T cells. The Journal of experimental medicine. 2001;193:1373-82.

11. Crotty S. Follicular Helper CD4 T Cells (TFH). Annu Rev Immunol. 2011;29:621-63.

12. Linterman MA, Rigby RJ, Wong RK, Yu D, Brink R, Cannons JL, et al. Follicular helper T cells are required for systemic autoimmunity. J Exp Med. 2009;206:561-76.

13. Behar SM, Lustgarten DL, Corbet S, Scharff MD. Characterization of somatically mutated S107 VH11-encoded anti-DNA autoantibodies derived from autoimmune (NZB x NZW)F1 mice. The Journal of experimental medicine. 1991;173:731-41.

14. Diamond B, Katz JB, Paul E, Aranow C, Lustgarten aD, Scharff MD. The Role of Somatic Mutation in the Pathogenic Anti-DNA Response. Annu Rev Immunol. 1992;10:731-57.

15. Yu D, Vinuesa CG. Multiple checkpoints keep follicular helper T cells under control to prevent autoimmunity. Cell Mol Immunol. 2010;7:198-203.

16. Morita R, Schmitt N, Bentebibel S-E, Ranganathan R, Bourdery L, Zurawski G, et al. Human blood CXCR5 + CD4 + T cells are counterparts of T follicular cells and contain specific subsets that differentially support antibody secretion. Immunity. 2011;34:108-21.

17. Simpson N, Gatenby PA, Wilson A, Malik S, Fulcher DA, SG Tangye et al. Expansion of circulating T cells resembling follicular helper T cells is a fixed phenotype that identifies a subset of severe systemic lupus erythematosus. Arthritis Rheumatism: Official Journal of the American College of Rheumatology. 2010;62:234-44.

18. Gensous N, Charrier M, Duluc D, Contin-Bordes C, Truchetet ME, Lazaro E, et al. T follicular helper cells in autoimmune disorders. Frontiers in Immunology, 2018;9.

19. Wells GA, Tugwell P, O'Connell D, Welch V, Peterson J, Shea B, et al. The Newcastle-Ottawa Scale (NOS) for assessing the quality of nonrandomized studies in meta-analyses, 2015.

20. Wan X, Wang W, Liu J, Tong T. Estimating the sample mean and standard deviation from the sample size, median, range and/or interquartile range. BMC Med Res Methodol. 2014;14:135.

21. Higgins J. G. Wells. Cochrane handbook for systematic reviews of interventions, 2011.

22. Liu C, Wang D, Lu S, Xu Q, Zhao L, Zhao J, et al. Increased Circulating Follicular Treg Cells Are Associated With Lower Levels of Autoantibodies in Patients With Rheumatoid Arthritis in Stable Remission. Arthritis Rheumatology. 2018;70:711-21.

23. Ma J, Zhu C, Ma B, Tian J, Baidoo SE, Mao C, et al. Increased frequency of circulating follicular helper T cells in patients with rheumatoid arthritis. Clinical and Developmental Immunology, 2012;2012.

24. Han J, Zhou Q, Li X, He J, Han Y, Jie H, et al. Novel function of hydroxychloroquine: Down regulation of T follicular helper cells in collagen-induced arthritis. Biomedicine Pharmacotherapy. 2018;97:838-43.

25. An LM, Li J, Ji LL, Li GT, Zhang ZL. Detection of peripheral follicular helper T cells in rheumatoid arthritis. Beijing da xue xue bao Yi xue ban = Journal of Peking University Health sciences. 2016;48:951-7.

26. Takeshita M, Suzuki K, Kondo Y, Morita R, Okuzono Y, Koga K, et al. Multi-dimensional analysis identified rheumatoid arthritis-driving pathway in human T cell. Ann Rheum Dis. 2019;78:1346-56.

27. Wang J, Shan Y, Jiang Z, Feng J, Li C, Ma L, et al. High frequencies of activated B cells and T follicular helper cells are correlated with disease activity in patients with new-onset rheumatoid arthritis. Clin Exp Immunol. 2013;174:212-20.

28. Liu R, Wu Q, Su D, Che N, Chen H, Geng L, et al. A regulatory effect of IL-21 on T follicular helper-like cell and B cell in rheumatoid arthritis. Arthritis Research and Therapy, 2012;14.

Page $13 / 20$ 
29. Cao G, Chi S, Wang X, Sun J, Zhang Y. CD4 + CXCR5 + pd-1 + t follicular helper cells play a pivotal role in the development of rheumatoid arthritis. Med Sci Monit. 2019;25:3032-40.

30. Zhang Y, Li Y, Lv TT, Yin ZJ. X. B. Wang. Elevated circulating Th17 and follicular helper CD4 + T cells in patients with rheumatoid arthritis. APMIS. 2015;123:659-66.

31. Nakayamada S, Kubo S, Yoshikawa M, Miyazaki Y, Yunoue N, Iwata S, et al. Differential effects of biological DMARDs on peripheral immune cell phenotypes in patients with rheumatoid arthritis. Rheumatology. 2018;57:164-74.

32. Chen XM, Li J, Zhang XY, Jin YB, Yu D, Sun XL, et al. Significance of different T follicular helper subsets in rheumatoid arthritis. Beijing da xue xue bao Yi xue ban = Journal of Peking University Health sciences. 2016;48:958-63.

33. Wang X, Yang C, Xu F, Qi L, Wang J, Yang P. Imbalance of circulating Tfr/Tfh ratio in patients with rheumatoid arthritis. Clinical Experimental Medicine. 2019;19:55-64.

34. Fukuyo S, Nakayamada S, Iwata S, Kubo S, Saito K, Tanaka Y. Abatacept therapy reduces CD28 + CXCR5 + follicular helper-like T cells in patients with rheumatoid arthritis. Clin Exp Rheumatol. 2017;35:562-70.

35. Costantino AB, Acosta CDV, Onetti L, Mussano E, Cadile II. P. V. Ferrero. Follicular helper T cells in peripheral blood of patients with rheumatoid arthritis. Reumatologia Clinica. 2017;13:338-43.

36. He J, Tsai LM, Leong YA, Hu X, Ma CS, Chevalier N, et al. Circulating precursor CCR7loPD-1hi CXCR5 + CD $4+\mathrm{T}$ cells indicate Tfh cell activity and promote antibody responses upon antigen reexposure. Immunity. 2013;39:770-81.

37. Arroyo-Villa I, Bautista-Caro MB, Balsa A, Aguado-Acin P, Bonilla-Hernan MG, Plasencia C, et al. Constitutively altered frequencies of circulating follicullar helper T cell counterparts and their subsets in rheumatoid arthritis. Arthritis Res Ther. 2014;16:500.

38. Aldridge J, Pandya JM, Meurs L, Andersson K, Nordström I, Theander E, et al. Sex-based differences in association between circulating T cell subsets and disease activity in untreated early rheumatoid arthritis patients. Arthritis research therapy. 2018;20:150.

39. Umeda M, Koga T, Ichinose K, Igawa T, Sato T, Takatani A, et al. CD4 + CD52lo T-cell expression contributes to the development of systemic lupus erythematosus. Clinical Immunology. 2018;187:50-7.

40. Niu Q, Huang ZC, Wu XJ, Jin YX, An YF, Li YM, et al. Enhanced IL-6/phosphorylated STAT3 signaling is related to the imbalance of circulating T follicular helper/T follicular regulatory cells in patients with rheumatoid arthritis. Arthritis Research and Therapy, 2018;20.

41. Kang ZJ, Liu YQ, Zhang ZG, Liu YY. H. J. Xu. Proportion of CCR7loPD-1hi follicular helper T cell in peripheral blood of systemic lupus erythematosus patients and its clinical role. Academic Journal of Second Military Medical University. 2018;39:1202-8.

42. Zhou H, Hu B, Zhaopeng Z, Liu J, Zhong Q, Fan Y, et al. Elevated circulating T cell subsets and cytokines expression in patients with rheumatoid arthritis. Clin Rheumatol. 2019;38:1831-9.

43. Fortea-Gordo P, Nuno L, Villalba A, Peiteado D, Monjo I, Sanchez-Mateos P, et al. Two populations of circulating PD-1hiCD4 T cells with distinct B cell helping capacity are elevated in early rheumatoid arthritis. Nat Immunol. 2019;58:1662-73.

44. Penatti A, Facciotti F, De Matteis R, Larghi P, Paroni M, Murgo A, et al. Differences in serum and synovial CD4 + T cells and cytokine profiles to stratify patients with inflammatory osteoarthritis and rheumatoid arthritis. Arthritis Research and Therapy, 2017;19.

45. Singh D, Henkel M, Sendon B, Feng J, Fabio A, Metes D, et al. Analysis of CXCR5 + Th17 cells in relation to disease activity and TNF inhibitor therapy in Rheumatoid Arthritis. Scientific reports. 2016;6:39474.

46. Rao DA, Gurish MF, Marshall JL, Slowikowski K, Fonseka CY, Liu Y, et al. Pathologically expanded peripheral T helper cell subset drives B cells in rheumatoid arthritis. Nature. 2017;542:110-4.

47. Yu D, Tan AH-M, Hu X, Athanasopoulos V, Simpson N, Silva DG, et al. Roquin represses autoimmunity by limiting inducible T-cell co-stimulator messenger RNA. Nature. 2007;450:299-303.

48. Gensous N, Charrier M, Duluc D, Contin-Bordes C, Truchetet M-E, Lazaro E, et al. T follicular helper cells in autoimmune disorders. Frontiers in immunology. 2018;9:1637.

49. Yao S, Chen L. PD-1 as an immune modulatory receptor. Cancer journal (Sudbury Mass). 2014;20:262-4.

50. Good-Jacobson KL, Szumilas CG, Chen L, Sharpe AH, Tomayko MM, Shlomchik MJ. PD-1 regulates germinal center B cell survival and the formation and affinity of long-lived plasma cells. Nature immunology. 2010;11:535.

51. Choi J-Y, Ho JH-e, Pasoto SG, Bunin V, Kim ST, Carrasco S, et al. Circulating follicular helper-like T cells in systemic lupus erythematosus: association with disease activity. 67. Hoboken: Arthritis \& rheumatology; 2015. pp. 988-99.

52. Francisco LM, Sage PT. A. H. Sharpe. The PD-1 pathway in tolerance and autoimmunity. Immunological reviews. 2010;236:219-42.

53. Liu C, Jiang J, Gao L, Wang X, Hu X, Wu M, et al. Soluble PD-1 aggravates progression of collagen-induced arthritis through Th1 and Th17 pathways. Arthritis research therapy. 2015;17:340-

54. Bauquet AT, Jin H, Paterson AM, Mitsdoerffer M, Ho I-C, Sharpe AH, et al. The costimulatory molecule ICOS regulates the expression of c-Maf and IL21 in the development of follicular T helper cells and T H-17 cells. Nature immunology. 2009;10:167.

55. Weber JP, Fuhrmann F, Feist RK, Lahmann A, Al Baz MS, Gentz L-J, et al. ICOS maintains the T follicular helper cell phenotype by down-regulating Krüppel-like factor 2. J Exp Med. 2015;212:217-33.

56. Tahiliani V, Hutchinson TE, Abboud G, Croft M, Salek-Ardakani S. OX40 Cooperates with ICOS To Amplify Follicular Th Cell Development and Germinal Center Reactions during Infection. Journal of immunology (Baltimore, Md: 1950), 2017;198:218 - 28.

Page $14 / 20$ 
57. Zheng B, Xu G, Chen X, Marinova E, Han S. ICOSL-mediated signaling is essential for the survival and functional maturation of germinal center B cells through the classical NF-KB pathway (IRM10P. 611). Am Assoc Immnol; 2015.

58. Rasheed AU, Rahn HP, Sallusto F, Lipp M, Müller G. Follicular B helper T cell activity is confined to CXCR5hilCOShi CD4 T cells and is independent of CD57 expression. Eur J Immunol. 2006;36:1892-903.

59. Singh JA, Saag KG, Bridges SL Jr, AkI EA, Bannuru RR, Sullivan MC, et al. 2015 American College of Rheumatology guideline for the treatment of rheumatoid arthritis. Arthritis rheumatology. 2016;68:1-26.

60. Raza K, Falciani F, Curnow SJ, Ross EJ, Lee C-Y, Akbar AN, et al. Early rheumatoid arthritis is characterized by a distinct and transient synovial fluid cytokine profile of T cell and stromal cell origin. Arthritis research therapy. 2005;7:R784-R95.

61. Van Nies J, Tsonaka R, Gaujoux-Viala C, Fautrel B. A. Van Der Helm-Van Mil. Evaluating relationships between symptom duration and persistence of rheumatoid arthritis: does a window of opportunity exist? Results on the Leiden early arthritis clinic and ESPOIR cohorts. Ann Rheum Dis, 2015;74:806-12.

62. van der Linden MP, Le Cessie S, Raza K, van der Woude D, Knevel R, Huizinga TW, et al. Long-term impact of delay in assessment of patients with early arthritis. Arthr Rhuem. 2010;62:3537-46.

\section{Figures}
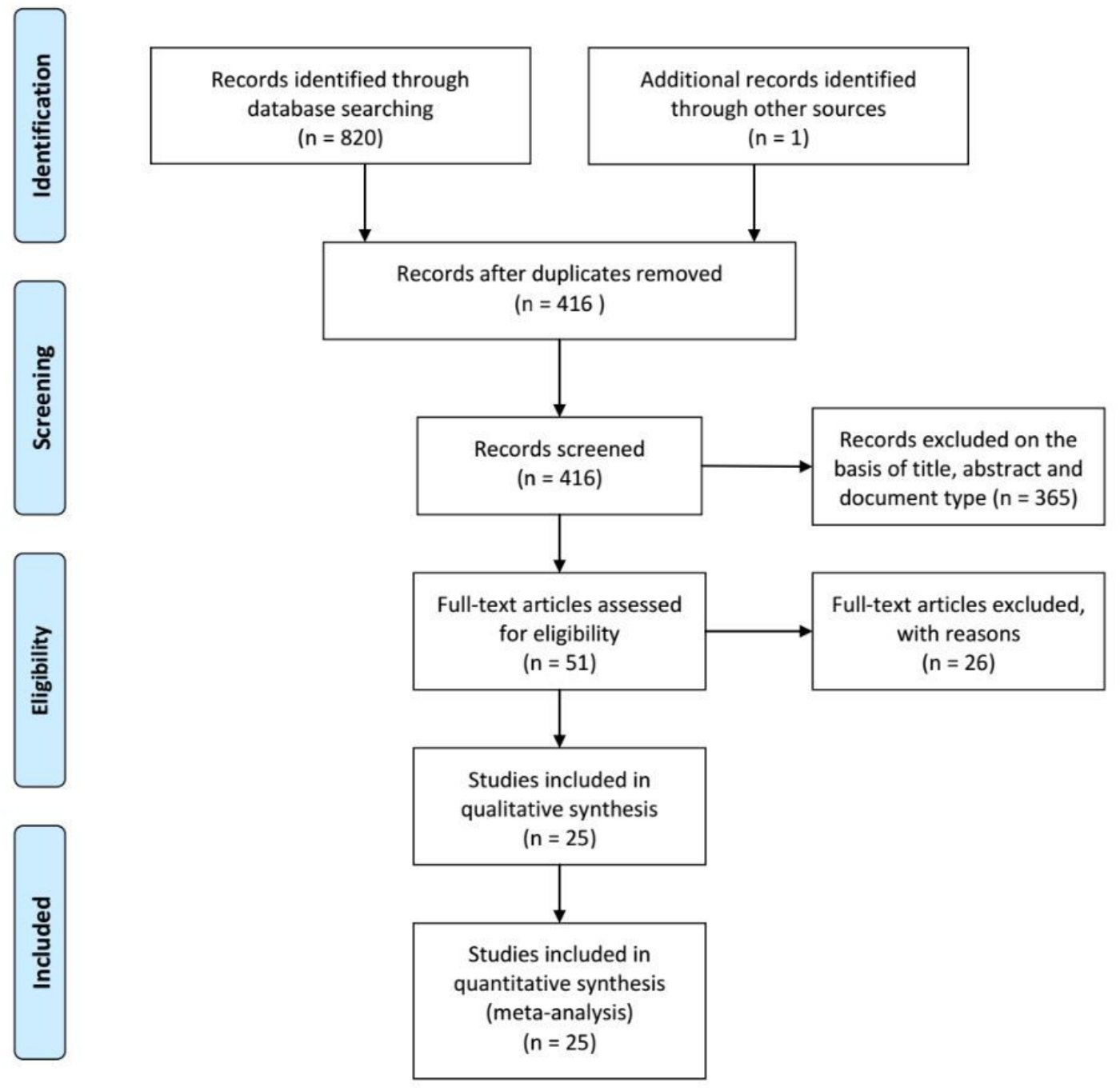

Figure 1

Flow chart of study selection process 


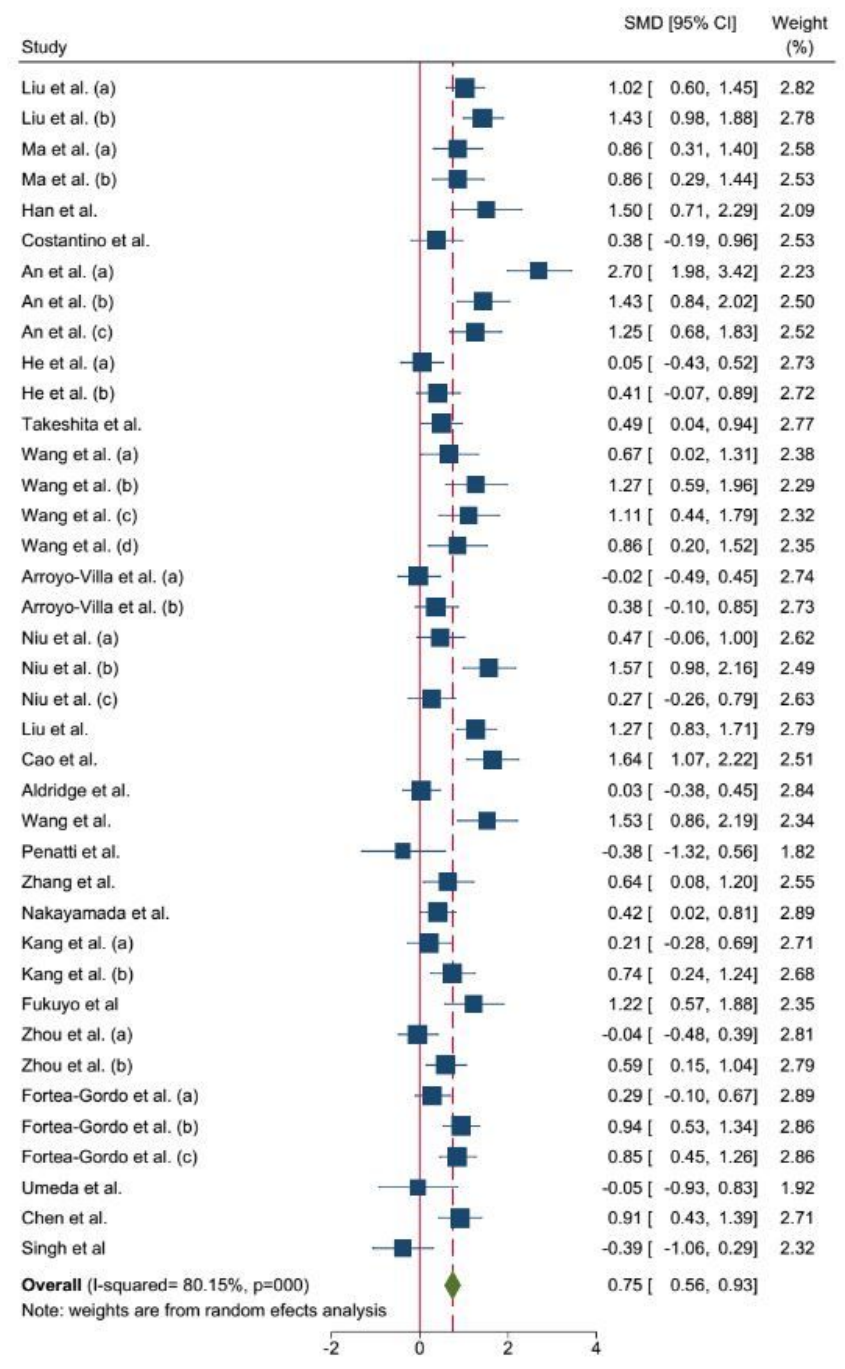

\section{Figure 2}

Overall standardized mean differences (SMD) of the proportion of Tfh cells in peripheral blood (PB) of RA versus HC. SMD of Tfh cell proportions in PB of RA patients compared with HCs, regardless of the Tfh cell definitions. Study identifier (a, b, c, d) was used to distinguish each study (table 1). 


\begin{tabular}{|c|c|c|}
\hline Study & $\mathrm{SMD}[95 \% \mathrm{Cl}]$ & $\begin{array}{c}\text { Weight } \\
(\%)\end{array}$ \\
\hline Liu et al. (a) & $1.02[0.60,1.45]$ & 5.27 \\
\hline Liu et al. (b) & $1.43[0.98,1.88]$ & 5.15 \\
\hline Ma et al. (a) & $0.86[0.31,1.40]$ & 4.53 \\
\hline Ma et al. (b) & $0.86[0.29,1.44]$ & 4.40 \\
\hline Costantino et al. & $0.38[-0.19,0.96]$ & 4.38 \\
\hline He et al. (a) & $0.05[-0.43,0.52]$ & 4.98 \\
\hline He et al. (b) & $0.41[-0.07,0.89]$ & 4.95 \\
\hline Takeshita et al. & $0.49[0.04,0.94]$ & 5.12 \\
\hline Wang et al. (a) & $0.67[0.02,1.31]$ & 3.99 \\
\hline Wang et al. (b) & $1.27[0.59,1.96]$ & 3.77 \\
\hline Wang et al. (c) & $1.11[0.44,1.79]$ & 3.84 \\
\hline Wang et al. (d) & $0.86[0.20,1.52]$ & 3.90 \\
\hline Cao et al. & $1.64[1.07,2.22]$ & 4.34 \\
\hline Aldridge et al. & $0.03[-0.38,0.45]$ & 5.33 \\
\hline Zhang et al. & $0.64[0.08,1.20]$ & 4.45 \\
\hline Fortea-Gordo et al. (a) & $0.29[-0.10,0.67]$ & 5.50 \\
\hline Fortea-Gordo et al. (b) & $0.94[0.53,1.34]$ & 5.39 \\
\hline Fortea-Gordo et al. (c) & $0.85[0.45,1.26]$ & 5.41 \\
\hline Chen et al. & $0.91[0.43,1.39]$ & 4.93 \\
\hline Zhou et al. (a) & $-0.04[-0.48,0.39]$ & 5.22 \\
\hline Zhou et al. (b) & $0.59[0.15,1.04]$ & 5.17 \\
\hline Overall $(I-$ squared $=69.52 \%, p=000)$ & $0.71[0.51,0.90]$ & \\
\hline Note: weights are from random effects analysis & & \\
\hline-1 & & \\
\hline
\end{tabular}

Figure 3

Standardized mean differences (SMD) of the proportion of Tfh cells in peripheral blood (BP) of untreated-RA (u-RA) patients versus healthy controls (HCs). SMD of Tfh cell proportions in PB of u-RA patients compared with HCs, regardless of the Tfh cell definitions. Study identifier (a, b, c, d) was used to distinguish each study (table 1). 
Wang et al. (b)

Wang et al. (c)

Wang et al. (d)

Cao et al.

Fortea-Gordo et al. (a)

Fortea-Gordo et al. (b)

Fortea-Gordo et al. (c)

Overall (I-squared $=60.26 \%, p=0.012$ )

Note: weights are from random effects analysis

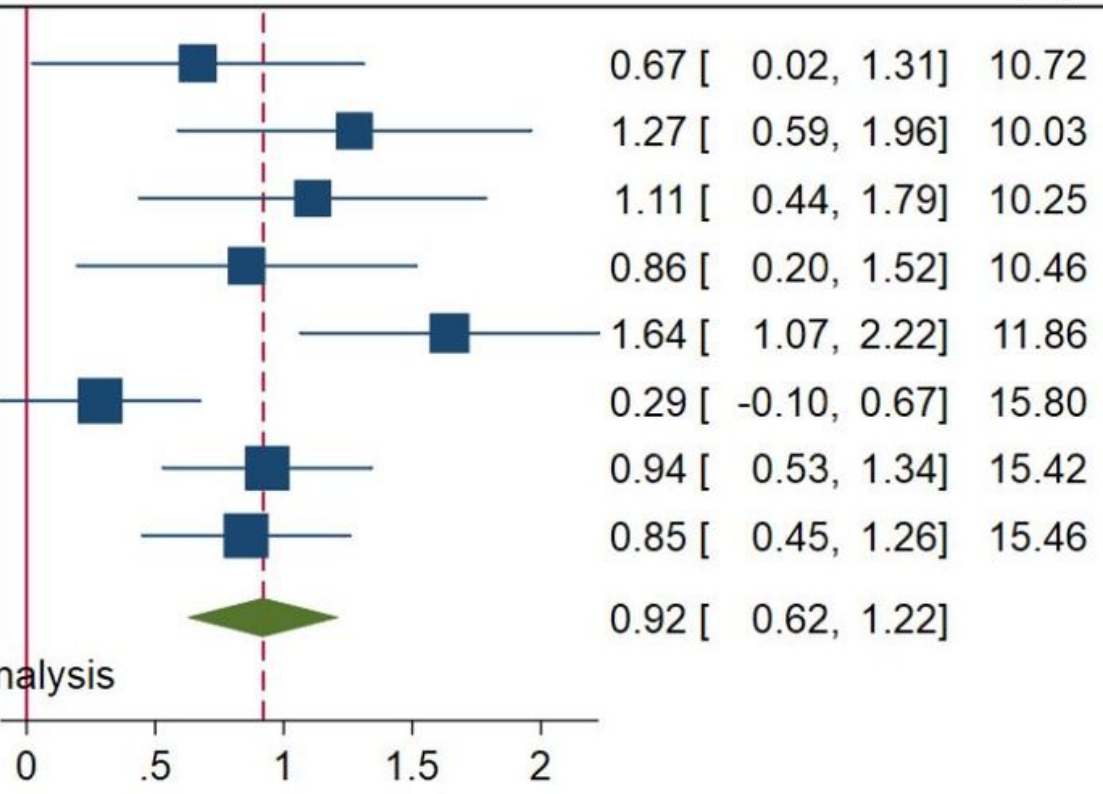

Figure 4

Standardized mean differences (SMD) of the proportion of Tfh cells in peripheral blood (PB) of early RA (e-RA) patients versus healthy controls (HCs). SMD of Tfh cell proportions in PB of e-RA patients compared to HC, regardless of the Tfh cell definitions. Study identifier (a, b, c, d) was used to distinguish each study (table 1). 


\section{A}

Study

SMD $[95 \% \mathrm{Cl}] \quad$ Weight

Liu et al. $\alpha$

Liu et al. $\beta$

Arroyo-Villa et al. $\alpha$

Arroyo-Villa et al. $\beta$

Niu et al. a

Niu et al. B

Niu et al. $y$

Chen et al.

Overall (I-squared $=48.83 \%, p=0.007)$

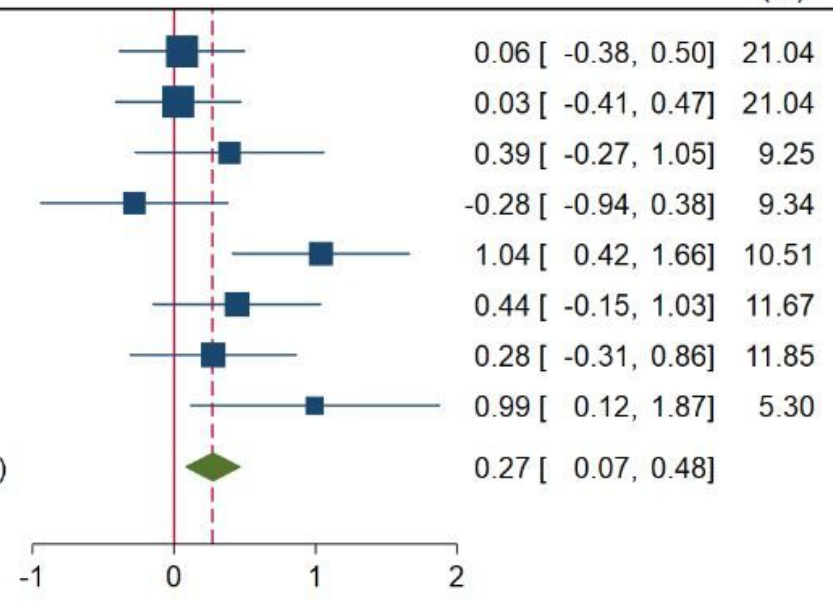

B

SMD $[95 \% \mathrm{Cl}] \quad$ Weight

Study

Liu et al. $\alpha$

Liu et al. $\beta$

Arroyo-Villa et al. $\alpha$

Arroyo-Villa et al. $\beta$

Niu et al. $\alpha$

Niu et al. $\beta$

Niu et al. $y$

Zhang et al.

Overall (I-squared $=83.4 \%, p=000)$

Note: weights are from random effects analysis

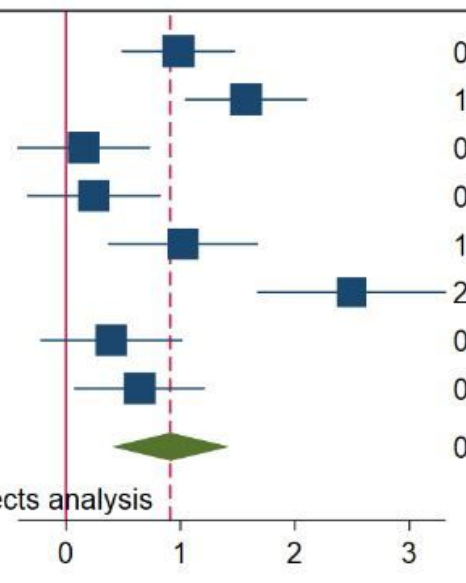

(\%)

0.98 [ $0.50,1.47] 13.31$

$1.57[1.05,2.10] 13.04$

0.16 [ $-0.42,0.73] 12.70$

0.24 [ $-0.33,0.82] 12.69$

$1.02[0.38,1.67] 12.17$

2.50 [ $1.68,3.31] 10.90$

0.40 [ $-0.22,1.01] 12.41$

0.64 [ $0.08,1.20] 12.79$

0.91 [ $0.40,1.42]$

0

Figure 5

standardized mean differences (SMD) of the proportion of T follicular helper (Tfh) cells in the peripheral blood (PB) of active-RA (a-RA) compared to remission-RA(r-RA). Tfh cell proportion in PB of a-RA compared with r-RA ( $A)$ and a-RA compared with $H C(B)$. Study identifier ( $a, \beta, \gamma)$ was used to distinguish each study (table 2). 
A

Study

SMD $[95 \% \mathrm{Cl}] \quad$ Weight

Ma et al.

Fortea-Gordo et al. ( $\alpha$ )

Fortea-Gordo et al.( $\beta$ )

Fortea-Gordo et al. ( $\mathrm{Y}$ )

A. Rao et al.

Overall $(I-$ squared $=3.85 \%, p=0.38)$

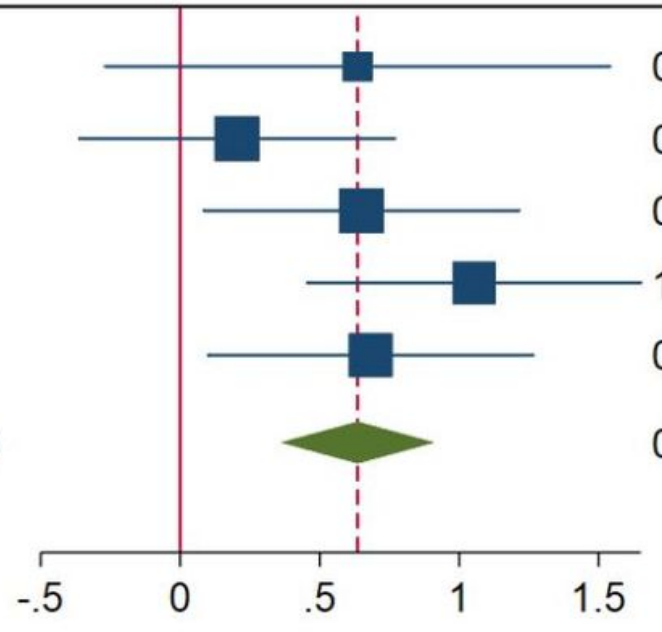

B

$0.64[-0.27,1.54] 9.23$

$0.20[-0.36,0.77] 23.66$

0.65 [ $0.08,1.22] 23.59$

1.05 [ $0.46,1.65] 21.18$

0.68 [ $0.10,1.26] 22.34$

$0.64[0.36,0.91]$

SMD [95\% Cl] Weight

Study

(\%)

Fortea-Gordo et al. ( $\alpha$ )

Fortea-Gordo et al.( $\beta$ )

Fortea-Gordo et al. (Y)

Fortea-Gordo et al. (ס)

Overall (I-squared $=68.92 \%, p=0.019)$

Note: weights are from random effects analysis

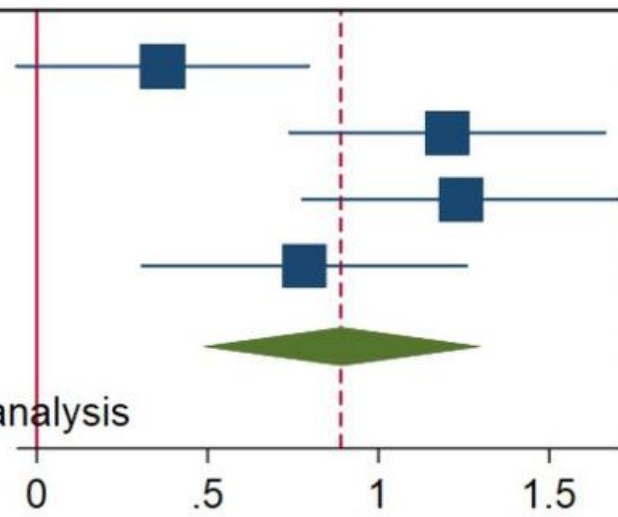

$0.37[-0.06,0.80] 26.00$

1.20 [ $0.74,1.66] 24.85$

$1.24[0.78,1.70] 24.77$

0.78 [ $0.31,1.26] 24.38$

$0.89[0.48,1.30]$

Figure 6

Standardized mean differences (SMD) of the proportion of T follicular helper (Tfh) cells in the peripheral blood (PB) of seropositive RA (S+RA) compared to seronegative RA (S-RA) and healthy control (HC). Tfh cell proportion in PB of S+RA compared to S-RA (A) and S+RA compared to HC (B). 